\title{
Exemptions Under the Bankruptcy Code: Using California's New Homestead Law as a Medium for Analysis
}

The Bankruptcy Reform Act of $1978^{1}$ permits individual debtors to claim as exempt specified portions of prebankruptcy real and personal property. ${ }^{2}$ The exemption shields these assets from distribution to creditors during and after the bankruptcy case. ${ }^{3}$ Section $522(\mathrm{~b})$ of the Bankruptcy Code permits the debtor to select these exemptions froin the Code's hist of exempt property or from the hist of exemptions provided by the debtor's state of domicile. ${ }^{4}$ However, section 522(b) also authorizes the states to "opt-out" of the Code's exemptions and limit their residents to exemptions available under state enforcement of judgment laws. ${ }^{5}$ Hence, while Congress has plenary authority to legislate in the field of bankruptcy, ${ }^{6}$ it has given the states the option of writmg the exemption portion of the Code. Thus far, thirty-six states

1. The Bankruptcy Reform Act of 1978, Pub. L. No. 95-598, 92 Stat. 2549 (1978) (codified at 11 U.S.C. $\S \S 101-151326$ (1982)) [hereinafter cited as Bankruptcy Code, or Code].

2. 11 U.S.C. $\S \S 522($ b), (d) (1982).

3. See Hertz, Bankruptcy Code Exemptions: Note on the Effect of State Law, 54 AM. BANKR. L.J. 339, 339-40 (1980) (providing a thorough definition of exemptions). Whether an exemption is effective against a particular secured creditor will depend upon whether the debtor's state of domicile permits a debtor to choose the exemptions provided in the Code, or limits the debtor to the exemptions allowed under state law. See infra text accompanying notes 18-26.

4. 11 U.S.C. $\$ 522(\mathrm{~b})(1)-(2)(A)$ (1982). If the debtor decides to utilize the state exemptions, the debtor may also exempt froin the estate any property that is exempt under nonbankruptcy federal law. This Comment will not discuss these latter exeinptions. For a partial listing of nonbankruptcy federal exemptions, see Debtors and Creditors, 1 NoRTON BANkR. L. \& Prac. (Callaghan) §26.03, at 5 (1982).

5. 11 U.S.C. $\$ 522(b)(1)$ (1982). In a state collection proceeding, a creditor will reduce his judgment to a levy or execution lien, and will sell the debtor's encumbered property in a forced sale. In these proceedings, the debtor is not neccssarily imsolvent, but has simply refused to pay the debt. Every state permits debtors to exeinpt a portion of equity in encuinbered properties froin the reach of creditors. The Bankruptcy Code permits the states to apply these exeinption laws to a federal bankruptcy proceeding.

6. The United States Constitution provides that Congress may "estabhish uniform Laws on the subject of Bankruptcies." U.S. CoNST. art. I, § 8, cl. 4. Congress first provided legislation in the field of bankruptcy in 1800, but there have been periods since then in which Congress provided no bankruptcy legislation. See Coninient, Bankruptcy Exemptions: Whether IIIinois's Use of the Federal 'Opt Out' Provision is Constitutional, 1981 S. ILL. U.L.J. 65, 78-79. Even during periods in which it has provided bankruptcy legislation, Congress has inade extensive use of state law. See Countryinan, The Use of State Law in Bankruptcy Cases (pts. 1 \& 2), 47 N.Y.U. L. REv. 407, 631 (1972) (discussing the use of state law under the Bankruptcy Act of 1898). The current Code also makes extensive use of state law. See, e.g., 11 U.S.C. \$ $522(\mathrm{~b})(2)(B)(1982)$ (protecting prop- 
including California have opted out of the Code's exemption list. ${ }^{7}$

In resolving substantive questions involving exemptions in opt-out jurisdictions, the bankruptcy courts have apphied the state law of the opt-out states. ${ }^{8}$ This follows from the opt-out provision; since the states provide the list of exemptions, the courts should look to the relevant state exemption laws for direction on how to apply the exemptions in bankruptcy. The bankruptcy courts, however, are sharply divided over whether various provisions of the Code (such as the trustee in bankruptcy's right to sell the debtor's property) supersede, as a 1natter of federal supremacy, the state exeinption laws, thus affecting the substantive rights of debtors to claim and secure exemptions in opt-out states. ${ }^{9}$

This division among courts is a matter of concern for consumer debtors and their creditors. Exemptions are central to Congress' goal of providing each debtor a "fresh start." 10 However, they also can prevent a creditor from receiving reasonable rehef. The lack of consistent and predictable holdings on the issue of exemptions has made it extremely difficult for attorneys to advise clients on the advantages and disadvantages of filing in bankruptcy, and for creditors to decide whether to extend credit to consumers. ${ }^{11}$

This Comment utilizes California's much hitigated and recently revised homestead exemption law ${ }^{12}$ as a vehicle for undertaking a systematic analysis of changes under the Bankruptcy Code of 1978. Specifically, this Comment exammes how the process of claiming and securing exemptions has changed and considers how the courts should

erty held in tenancy by entirety where such property is protected under state law); $i d . \S 544(\mathrm{~b})$ (allowing the trustee to avoid interests avoidable under state law).

7. See infra notes 27-29.

8. See, e.g., First Nat'l Bank v. Norris, 701 F.2d 902 (11th Cir. 1983); In re Wilson, 694 F.2d 236 (11th Cir. 1982); In re Schneider, 9 Bankr. 488 (N.D. Cal. 1981); In re Miles, 35 Bankr. 52 (Bankr. E.D. Cal. 1983); In re Nieınyjski, 26 Bankr. 466 (Bankr. D.N.M. 1983); In re Carr, 19 Bankr. 173 (Bankr. N.D. Fla. 1982); In re Kimball, 2 Bankr. 560 (Bankr. W.D. La. 1980).

9. For a striking example of this conflict, compare Rhodes v. Stewart, 705 F.2d 159 (6th Cir. 1983) with In re Locarno, 23 Bankr. 622 (Bankr. D. Md. 1982).

10. For an excellent discussion of the concept of a "fresh start" and the role of exemptions, see In re Neiheisel, 32 Bankr. 146, 148-62 (Bankr. D. Utah 1983) (analyzing the legislative history).

11. For an illustration of this division within a judicial circuit, compare In re Foster v. City Sav. \& Loan, 16 Bankr. 467 (Bankr. N.D. Ohio 1981) with Curry v. Associates Fin. Servs., 11 Bankr. 716 (N.D. Ohio), rev'd on other grounds, 698 F.2d 298 (6th Cir. 1981) (disagreeing over the proper interpretation of the ben avoidance provision). While the bankruptcy courts have tended to achieve a modicuun of consensus within the judicial circuits, the authoritativeness of these decisions is questionable because of contrary holdings by higher courts in other jurisdictions. Compare Mattcr of McManus, 681 F.2d 353 (5th Cir. 1982) with In re Baxter, 19 Bankr. 674 (Bankr. 9th Cir. 1982) (also disagreeing over the proper interpretation of the lien avoidance provision).

12. CAL. Clv. Proc. CODE $\$ \S 704.710-.850$ (West Supp. 1984) (codifying the Enforcement of Judgments Law, ch. 1364, §2, 1982 Cal. Stat. 5070). 
resolve the conflicts that arise between exemptions under state law and various provisions of the Code. A general test is proposed for resolving conflicts mvolving claims of exemptions in opt-out states. This test is then applied to California's homestead exemption to deternime whether provisions of the Code alter debtors' substantive exeinption rights to claim both California's homestead exemption and exemptions arising under the Bankruptcy Code.

Part I discusses the exemption and procedural provisions of the Bankruptcy Code, the purposes of exemptions im bankruptcy, and the various types of opt-out statutes. It then isolates three categories of Code provisions that arguably affect debtors' exemption rights, and that have been the subject of extensive bankruptcy litigation. Part II coinpares the current Bankruptcy Code with its predecessor, the Bankruptcy Act of $1898,{ }^{13}$ to explain why these conflicts arose. A framework for resolving these conflicts is then proposed. Part III applies this framework to California's lioinestead excmption law and analyzes soine of the problems that arise in interpreting this law. Finally, Part IV examines the specific sections of the Code that inay affect state exemption provisions. Conflicts between the California homestead law and these Code sections are then resolved using the framework developed in Parts II and III.

Federal and State Exemption Laws in BankRuptcy

The bankruptcy laws of the United States have always offered debtors the opportunity to exempt property from creditors. ${ }^{14}$ The fundamental purpose behind exemptions in bankruptcy is to ensure that the debtor is not left destitute and dependent upon the public purse after distribution of his assets to creditors. ${ }^{15}$ Along with the discharge of debts, exemptions are the principal means by which the bankruptcy proceeding allows the debtor to rehabilitate himself and his family financially. ${ }^{16}$ Thus, exemptions provide the debtor witlı a meaningful

13. The Bankruptcy Act of 1898, ch. 541, 30 Stat. 544, as amended by 52 Stat. 847 (1938) (repealed 1979) [hereinafter cited as 1898 Act or Act].

14. For an extensive discussion of the exemption provisions of the various bankruptcy laws, see Comment, Bankrupicy Exemptions: Critique and Suggestions, 68 YALE L.J. 1459, 1460-63 (1959).

15. H.R. REP. No. 595, 95th Cong., 1st Sess. 126, reprinted in 1978 U.S. CoDE CoNG. \& AD. NEws 5963, 6087 [hereinafter cited as HousE REPORT].

16. Id at 118, reprinted in 1978 U.S. CODE CONG. \& AD. NEws at 6078 ("the debtor is given adequate exemptions and other protections to ensure that bankruptcy will provide a fresh start"); id. at 128, reprinted in 1978 U.S. CODE CONG. \& AD. NEws at 6089 ("Perhaps the most important element of the fresh start for a consumer debtor after bankruptcy is discharge."). Professor Vukowich has argued that the opt-out provision violates Congress' fresh start pohcy. Vukowich, Debtors' Exemption Rights Under the Bankruptcy Reform Act, 58 N.C.L. REv. 769, 801-02 (1980). 
fresh start, and "shift the burden of providing the debtor with minimal financial support from society to the debtor's creditors." 17

\section{A. Federal Exemption Laws}

The exemption provision of the Bankruptcy Code is actually two statutes in one. The first statute permits the debtor to choose between the Code's exeinptions and those provided by the debtor's state of doinicile. ${ }^{18}$ Section 522(d) of the Code offers a comprehensive and modestly generous slate of eleven exeinptions which includes, among other things, exemptions for tools of trade, personal effects, motor vehicles, household goods, and a $\$ 7500$ homestead exemption. ${ }^{19}$ If the debtor is not a homeowner or does not wish to protect equity in the home, the $\$ 7500$ exemption becomes a "wildcard" and may be used to protect any of the debtor's property. ${ }^{20}$ Where a husband and wife are jomed in a bankruptcy case, each may claim a full slate of Code or state exeinptions. ${ }^{21}$ The Bankruptcy Code's exemption list was the end product of the protean efforts of a generation of bankruptcy scholars and judges. These reformers urged Congress to pass a uniform and modern exeinption provision that would offer debtors a fresh start, avoid unnecessary litigation, and provide the creditor with a fair return. ${ }^{22}$

The second exeinption provision of the Code, however, allows the states to negate completely the Code's exemptions and apply only their own exeinption provisions to the bankruptcy case. Under this so-called "opt-out provision," section 522(b)(1), a debtor's state of domicile may limit the debtor to exemptions available under both state and federal

17. Resnick, Prudent Planning or Fraudulent Transfer? The Use of Nonexempt Assets to Purchase or Improve Exempt Property on the Eve of Bankruptcy, 85 CoM. L.J. 238, 241 (1980) (stating this effect as a normative goal of exemptions).

18. 11 U.S.C. \& 522(b)(1)-(2)(A) (1982).

19. Id. $\S 522(\mathrm{~d})(\mathrm{l})-(11)$.

20. Id. $\$ 522($ d)(1), (5). Subsection (5) provides an additional $\$ 400$ exenuption which may be added to the $\$ 7500$ honiestead exemption. See also Augustine v. United States, 675 F.2d 582, 585 86 (3d Cir. 1982) (holding that debtors may utilize $\$ \S 522(\mathrm{~d})(\mathrm{l})$ and (5) to protect any property, including property not listed in the Code's slate of exemptions). Congress recently aniended $\S 522$ (d)(5) to provide that the debtor may only use up to $\$ 3750$ of auy unused portion of the exemption provided $\mathrm{m} \S 522(\mathrm{~d})(\mathrm{l})$ as a wildcard. The new provision apphes to cases filed 90 days after July 11, 1984. Bankruptcy Amendments and Federal Judgeship Act of 1984, Pub. L. No. 98353, $\$$ 306(c), 553(a), 98 Stat. 333 [hereinafter cited as Bankruptcy Amendments].

21. 11 U.S.C. $\$ 522(\mathrm{~m})$ (1982). But see infra text accompanying notes 153-69 (discussing limitations ou the right of joint debtors to claim Code and state exemptions).

22. See REPORT OF THE COMM'N ON THE BANKRUPtCY LAwS OF THE UNITEd STATES, (pts. 1 \& 2), H.R. Doc. No. 137, 93d Cong,, 1st Sess. 169-71 (1973) [heremafter cited as Commission REPORT]; Countryman, Consumer Bankruptcy-Some Recent Changes and Some Proposals, 19 U. KaN. L. REv. 165, 167 (1971); Vukowich, The Bankruptcy Commission's Proposal Regarding Bankrupts' Exemption Rights, 63 CALIF. L. REv. 1439, $1441-45$ (1975); Comment, supra note 14, at 1507-14. 
nonbankruptcy law. ${ }^{23}$ The inclusion of this provision in the Bankruptcy Code was the result of a "last minute" compromise between House and Senate conferees. ${ }^{24}$ Commentators have criticized this provision, describing it variously as "bizarre," 25 and "as a retreat froin the commitment to the preservation of the debtor's fresh start."26

\section{B. State Opt-Out Laws}

The state opt-out laws tend to follow three general patterns. The most common type of state law simply declares that the Code's exemptions are not authorized and that the debtor nust meet the substantive requirements of the state's nonbankruptcy exemption laws to claim the property as exeinpt in bankruptcy. ${ }^{27} \mathrm{~A}$ second, less cominon type of statute also disallows the Code's exemptions, but specifies exemptions which apply only in bankruptcy; the debtor may not choose from the state's nonbankruptcy exemptions. ${ }^{28}$ The third type of opt-out statute exists only in California. This statute permits an unmarried person to claim either the state's or the Code's exemptions, but forces a husband and wife to jointly choose between these exemption slates. ${ }^{29}$ Cahforma's exemption law is, overall, more generous than the Code's. California's hoinestead exemption, for example, permits the debtor to protect between $\$ 30,000-\$ 45,000$ of equity in a house, ${ }^{30}$ as compared to

23. 11 U.S.C. $\$ 522(b)(1)$ (1982).

24. Hertz, supra note 3 , at 341.

25. Aaron, The Bankruptcy Reform Act of 1978: The Full-Employment-For-Lawyers Bill (pt. 2), 1979 Utah L. Rev. 175, 183-84.

26. Comment, Protection of Debtor's "Fresh Start" Under the New Bankruptcy Code, 29 CATH. U.L. REv. 843, 865 (1980).

27. Ala. Code § 6-10-11 (Supp. 1983); Ariz. Rev. Stat. ANN. § 33-1133 (Supp. 1983-84); Colo. Rev. Stat. § 13-54-107 (Supp. 1983); Fla. Stat. ANn. § 222.20 (West Supp. 1984); Idaho CODE § 11-609 (Supp. 1984); An Act to Codify Civil Procedure, § 12-1201, ILl. ANN. STaT. ch. 110, § 12-1201 (Smith-Hurd Supp. 1984); IND. CODE ANN. §34-2-28-0.5 (West 1983); lowA CODE ANN. §627.10 (West Supp. 1984-85); KAN. Stat. ANN. § 60-2312 (1983); KY. Rev. Stat. ANN. $\S 427.170$ (Bobbs-Merrill Supp. 1982); LA. Rev. Stat. ANN. $§ 13.3881$ (B) (West Supp. 1984); Me. Rev. Stat. AnN. tit. 14, § 4426 (Supp. 1983-84); MD. CTs. \& Jud. Proc. Code ANn. \& 11-504(g) (1984); Mo. ANN. STAT. \& 513.427 (Vernon Supp. 1984); MoNT. Code ANN. \& 31-2-106 (1983); Neb. Rev. Stat. \& 25-15105 (Supp. 1982); Nev. Rev. STat. \& 21.090(3) (1983); N.H. Rev. Stat. ANN. § 511: 2-a (1983); N.C. GEN. STAT. § 1c-1601 (1983); N.D. CenT. Code § 28-22-17 (Supp. 1983); Okla. Stat. ANN. tit. 31, § 1(B) (West Supp. 1983-84); OR. Rev. Stat. $\$ 23.305$ (1983); S.C. Code ANN. § 15-41-425 (Law. Co-op. Supp. 1983); Tenn. Code ANN. § 26-2-112 (1980); UTAH CODE ANN. § 78-23-15 (Supp. 1983); VA. Code § 34-3.1 (Supp. 1983); WYo. STAT. § 1-20109 (Supp. 1984).

28. Alaska Stat. § 09.38.055 (1983); ARk. Stat. ANn. § 36-211 (Supp. 1983); Del. Code ANN. tit. 10, § 4914 (Supp. 1982); GA. CODE ANN. § 51-1301.1 (Supp. 1984); N.Y. DEBT. \& CRED. LAW §§ 282, 284 (McKinney Supp. 1983); OHio Rev. CODE ANN. § 2329.66(4)(a), 2329.662 (Page Supp. 1983) (§ 2329.662 repealed effective Jan. 1, 1985); W. VA. CODE § 38-10-4 (1984).

29. Cal. Civ. Proc. Code $\& 703.130$ (b) (West Supp. 1984).

30. Id. § 704.730 . 
the $\$ 7500$ homestead exemption in the Code. ${ }^{31}$

\section{Procedural Provisions of the Code}

The Bankruptcy Code and Rules provide the procedure for claiming exemptions in both opt-out and Code-exemption states. ${ }^{32}$ The debtor commences the bankruptcy case by filing a petition in bankruptcy. ${ }^{33}$ All of the debtor's property, including property that may be claimed as exempt, is transferred to the bankruptcy "estate." 34 The trustee in bankruptcy takes over administration of this property pursuant to the provisions of the Code and the court's supervision. ${ }^{35}$ The debtor then selects his exemptions from the applicable slate of exemptions and lists those assets as exempt. ${ }^{36}$ Creditors inay object to and challenge these claims. ${ }^{37}$ The debtor may also need to "avoid" certain hens encumbering the property in order to secure his exemption on it. ${ }^{38}$ For example, in California, if the debtor's home has a market value of $\$ 100,000$ and is subject to a $\$ 100,000$ judgment lien, the debtor inust avoid or extinguish $\$ 45,000$ of the lien (assuming the debtor is entitled to a $\$ 45,000$ exemption) ${ }^{39}$ to take full advantage of the state's homestead exemption. After bankruptcy, the debtor retains the exempt property free from the avoided part of the lien.

If there is equity left after the debtor has claimed his exemption and after "unavoidable" liens are accounted for, the trustee will sell the property and distribute the proceeds to unsecured creditors in the forn of a dividend. ${ }^{40}$ If no equity reinains, the trustee must return the property to the debtor. ${ }^{41}$ The debtor receives a discharge of his debts in exchange for allowing creditors to divide up his nonexempt assets. ${ }^{42}$ These creditors may not seek satisfaction on their claims after the dis-

31. 11 U.S.C. \& 522(d)(1) (1982).

32. See In re Burgess, 1 Bankr. 421 (Bankr. M.D. Tenn. 1979) (decided under the 1898 Act but stating that even though federal bankruptcy law uses state law to determine substantive rights, federal bankruptcy law governs procedure).

33. 11 U.S.C. $\$ 301$ (1982). Creditors may force the debtor into bankruptcy. Id. \$303. For an excellent synopsis of the process of commencing a bankruptcy case, see Pedlar, Community Property and the Bankruptcy Reform Act of 1978, 11 ST. MARY's L.J. 349, 352-57 (1979).

34. 11 U.S.C. $\$ 541(\mathrm{a})(1982)$.

35. Id. $\$ 704$.

36. Id. $\S 522$; BANKRUPTCY RULES $\S \S 1007(\mathrm{~h}), 4003(\mathrm{a})$ (the former governing property acquired after the petition in bankruptcy is filed).

37. BANKRUPTCY RULES $\S 4003$ (b).

38. 11 U.S.C. $\$ 522(f)(1982)$. For a detailed description of this provision see infra text accompanying notes $135-52$.

39. CAL. Crv. Proc. Code $\$ 704.730$ (West Supp. 1984) (stating the amonnt of the homestead exemption).

40. 11 U.S.C. $\$ 726$ (1982).

41. Id. $\S 554$.

42. The Code may deny the debtor a discharge for the reasons specified in 11 U.S.C. $\S 523$ (1982). 
charge and close of the bankruptcy case. ${ }^{43}$

\section{Conflicts Between Various Provisions of the Code and Exemptions Provided Under State Opt-Out Laws}

Since the Bankruptcy Code becaine operative in $1979,{ }^{44}$ the bankruptcy courts have witnessed a virtual explosion in the number of reported cases dealing with exemptions. ${ }^{45}$ Though the specific claims in these cases have varied immensely, inost of the cases share a common issue: whether various provisions of the Code alter the substantive rights that a debtor possesses under his opt-out state's exemption laws, and hence "preempt" or "supersede" the state exemption laws. In California, hitigation of this issue has focused almost exclusively upon the state's holnestead exemption law. ${ }^{46}$

The specific provisions of the Code that arguably affect exemption rights in California and other jurisdictions fall into three broad categories. First, the Code contains provisions that facilitate claiming and securing exemptions. As previously mentioned, the Code allows the debtor to "avoid" certain liens that impair the debtor's full exemption. ${ }^{47}$ In California, for example, a debtor may not claim a homestead exemption on property encumbered by a lien recorded before the

43. 11 U.S.C. $\$ 524$ (1982). Since the bankruptcy case does not affect the rights of secured creditors, these creditors may seek satisfaction after the bankruptcy case. See, e.g., In re Pierce, 29 Bankr. 612 (Bankr. E.D.N.C. 1983).

44. A one-year transition period followed the passage of the Code. See Klein, The Bankruptcy Reform Act of 1978, 53 AM. BANKR. L.J. 1, 3 (1979).

45. Part of this increase must be attributed to the general proliferation in bankruptcy filings. In 1977, there were 181,194 straight (liquidation) bankruptcy filings. In 1982, there were 367,141 filings. 1982 ADMIN. OfFICE U.S. CTS., ANN. REP. 15 (1982). However, the increase in reported cases involving exemptions las exceeded the general increase in filings. For example, from 1966 77, West's DECENNIAL DIGEST reported 83 cases involving a dispute over whether a bankrupt was entitled to an exemption. EIGHTH DECENNIAL Digest, Bankruptcy, key $392-99$ (West 1977). During a one-year reporting period, 1982-83, however, West's BANKRUPTCY DIGEST reported 193 cases involving a dispute over exemption rights in bankruptcy. BANKRUPTCY DIGEST, key 395-99 (West Sept. 1983) (reporting West's BANKRUPTCY REPORTER volumes 21-29). Hence tlie number of reported cases involving exemptions during this one-year period is over twice tlat reported during a ten-year period under the 1898 Act.

46. In this Comment, references to bankruptcy cases arising in California cover cases in which a federal bankruptcy court applies California's exeinption law. The choice of law is determined by the debtor's domicile 180 days before the commencement of the bankruptcy case. 11 U.S.C. $\$ 522(b)(2)(A)(1982)$. For cases arising in California involving the effect of the Bankruptcy Code upon California's hoinestead exeinption law, see, e.g., In re Sclineider, 9 Bankr. 488 (N.D. Cal. 1981) (Code provisions do not affect debtor's homestead rights in undivided interests); In re Dahdah, 20 Bankr. 665 (Bankr. 9th Cir. 1982) (husband and wife may "stack" Code and state exemptions); In re Baxter, 19 Bankr. 674 (Bankr. 9th Cir. 1982) (spouses entitled to liomestead exeinption on preexisting liens); In re Skipwith, 9 Bankr. 730, 732-34 (Bankr. S.D. Cal. 1981) (California need not offer joint debtors two lionesteads).

47. See supra text accompanying notes 38-39. 
debtor acquired or moved into the home. ${ }^{48}$ Some bankruptcy courts have held, however, that when a debtor files in bankruptcy, the debtor may utilize the "avoidance" provision of the Bankruptcy Code to defeat the preexisting hens and to claim an exemption. ${ }^{49}$ Allowing the Code's avoidance provision to supersede state law significantly imcreases the debtor's right to exeinpt property coinpared to that provided by California law. A second facilitatimg provision of the Code states that "[the exemption provision of the Code] shall apply separately with respect to each debtor in a joint case."50 The bankruptcy courts have generally held that this section gives both a husband and a wife joined in a bankruptcy case the right to claim Code or state exemptions, even though many states, mcluding California, forbid joint debtors from each claiming the Code's exemptions. ${ }^{51}$ This interpretation of the Code virtually doubles the ability of joint debtors to defeat the claims of creditors compared to that permitted by the states.

The second category of Code provisions, unlike the first, may limit the right of debtors to claim exemptions and protect their property against forced sale. The Code gives the trustee in bankruptcy special powers to preserve assets for the estate. ${ }^{52}$ Where a debtor owns an undivided interest in property, the Code permits the trustee to sell, under certaim circumstances, both the debtor's and nondebtor's interest in the property. ${ }^{53}$ The proceeds from the sale are divided between the nondebtor co-owner and the unsecured creditors. This power inay permit the trustee to sell assets of the debtor which creditors im opt-out states cannot reach. If the trustee's sale power is interpreted to permit

48. Cal. Civ. Proc. Code $\$ 704.710$ (c) (West Supp. 1984).

49. See cases cited supra note 46. But see In re Falck, 12 Bankr. 835 (Bankr. C.D. Cal 1981) (holding that debtor in bankruptcy may not avoid nonpossessory nonpurchase-money security interest where the state law does not permit the claiming of exemptions on sueh interests).

50. 11 U.S.C. \$ 522(m) (1982).

51. See, e.g., In re Ageton, 14 Bankr. 833 (Bankr. 9th Cir. 1981). But see In re Goering, 23 Bankr. 1010 (Bankr. N.D. Ill. 1982). On June 29, 1984, the House and Senate amended this provision as part of a general revision of the Bankruptcy Code. H.R. 5174, 98th Cong., 2d Sess. $\S \S 306(a)$, (b) (1984). The President signed the bill into Law on July 10, 1984. Bankruptcy Amendineuts, supra note 20, $\$$ 306(a), (b). However, Congress did not give this provision retroactive effect. Instead, Congress provided that this and other substantive provisions would become effective 90 days after enactment of the revision. Id. at $\S 553$ (a). Bankruptcy cases can take four to five years before they are concluded. For example, cases arising under the 1898 Act are still being litigated and reported. Heuce, for at least the next several years, courts will face claims by joint debtors that they are entitled to claim Code and state exemptions.

52. This Comment will not discuss the trustee's asset-preserving powers under 11 U.S.C. $\S 544$ (1982) (the "strong arm" power). Relatively few difficult cases have arisen involving whether the trustee may utilize this power to alter debtors' exemption rights. For a discussion of soine of these problems, see In re Weiman, 22 Bankr. 49 (Bankr. 9th Cir. 1982) (court divided over whcther the trustee could use his status as a lypothetical hen holder to defeat the debtor's claim of a homestead exemption); see also In re Bouchard, 11 Bankr. 869 (Bankr. S.D. Cal. 1981) (providing the proper resolution of these issues).

53. 11 U.S.C. $\$ 363(\mathrm{~h})$, (i), (j) (1982). 
the sale of property that cannot otherwise be sold under state law, then it would significantly reduce the ability of a debtor in an opt-out state to use an exeunption to prevent the forced sale of property. ${ }^{54}$

Finally, soine courts have held that the Code places limits upon the authority of opt-out states to deny exemptions to debtors. As discussed above, the Code provides a comprehensive and detailed list of exemptions. ${ }^{55}$ Several courts (although a minority) have held that Congress, im passing a slate of exemptions, imtended to require opt-out states to provide exemptions comparable to those offered in the Code. ${ }^{56}$ This doctrine, for example, has been mvoked to invalidate a state exeinption law that did not offer nonhomeowners an exemption comparable to that offered homeowners. ${ }^{57}$

The foregoing provisions of the Code could, if so interpreted, substantially alter the rights of debtors to claim exemptions in opt-out states. In California, for example, the Code's "avoidance" provision inay permit debtors to obtain rights to exeinpt property that they could not exempt under the state's already generous exemption law. A fully secured lien holder who would obtain full satisfaction under state law may receive little or no compensation in bankruptcy under the Code. ${ }^{58}$ On the other hand, the trustee's sale power may pernit the trustee to sell property of the debtor that a debtor could preserve under state law. Thus, as imterpreted, these provisions of the Code represent an important exception to the general rule that the state law of an opt-out state determines the debtor's right to exempt property in bankruptcy. ${ }^{59}$

Unfortunately, the courts have not developed a consistent inethod for determining whether the foregoing provisions affect debtors' exeinption rights im opt-out states. Instead, the judicial opinions to date lave produced a mélange of rules. Some courts have lield that where a

54. In California, for example, a husband and wife can usually protect a home held in joint tenancy where a creditor has only obtaimed judgment agamst one spouse. However, $\$ 363(\mathrm{~h})$ generally permits the trustee to sell such property. This is discussed in detail infra in text accompanying notes 171-207.

55. See supra text accoinpanying notes 18-22.

56. See, e.g., In re Locarno, 23 Bankr. 622 (Bankr. D. Md. 1982); In re Balgemann, 16 Bankr. 780 (Bankr. N.D. Ill. 1982). This doctrine has been rejected in inost jurisdictions. See In re Neiheisel, 32 Bankr. 146, 156-57 \& nn.57-58 (Bankr. D. Utah 1983) (discussing the various holdings among the jurisdictions).

57. Locarno, 23 Bankr. at 622.

58. If, for example, a creditor in California filed a judicial hen before the debtor acquired his hoine, the lien holder would have rights in the equity in that hoine superior to the debtor's exemption rights under the state law. CAL. CIv. Proc. CODE \$ 704.710(c) (West Supp. 1984). If, however, the debtor filed in bankruptcy and was permitted to "avoid" the lien, then the secured creditor would become an unsecured creditor to the extent that the equity in the home did not cover the lien. 11 U.S.C. $\$ 506$ (a) (1982). The creditor would thus be limited to a dividend along with the other unsecured creditors. II U.S.C. $\$ \$ 507(a)(4), 726$ (1982).

59. See cases cited supra note 8. 
state opts out of the Code's exemptions, the state exemption laws are unaffected by the various nonexemption provisions of the Code. ${ }^{60}$ These courts have stated that a provision of the Code supersedes a state exemption law only to the extent that the two laws "actual[ly] conflict." Since the Code permits the states to write the exemption portion of the Code, these courts have reasoned that state laws simply cannot conflict with the Code. ${ }^{62}$ Other courts, in contrast, have held that a state exemption law must comport with what they perceive as the general purposes of the federal bankruptcy law. ${ }^{63}$ These courts have held that the opt-out states inust provide a minimum level of exeinptions because Congress has sought to provide each debtor a fresh start, and hence has placed limits upon state authority. The courts have produced little explanation for why they have reaclied these results, or how they have reached them.

II

Resolving Conflicts Between State Law and BANKRUPTCY CODE Provisions

This Part articulates a general test for determining the substantive effect of the Code upon opt-out state exemption laws. This test is developed by coinparing the exemption provision of the Code with that of the former bankruptcy act.

\section{A. Comparison of Past and Present Bankruptcy Exemption Provisions}

The Bankruptcy Act of 1898 did not provide a slate of exemptions from which the debtor could choose. Rather, section 6 of the Act provided that: "This Act shall not affect the allowance to bankrupts of the exemptions which are prescribed by the laws of the United States or by the State laws in force at the time of the filing of the petition. . . ."64

60. See, e.g., In re McManus, 681 F.2d 353, 355 (5th Cir. 1982) ("Section 522(b) expressly grants the states broad discretion and an open-ended opportunity to determine what property may be exempt from the bankruptcy estate," so long as state law does not conflict with nonbankruptcy federal exemptions); In re Sullivan, 680 F.2d 1131, 1136 (7th Cir.), cert. denied, 459 U.S. 992 (1982); Foster v. City Loan \& Sav. Co., 16 Bankr. 467 (N.D. Ohio 1981); In re Evans, 25 Bankr. 105, 110 (Bankr. N.D. Tex. 1982); In re Goering, 23 Bankr. 1010 (Bankr. N.D. Ill. 1982).

61. See, e.g., Goering, 23 Bankr. at 1010, 1013.

62. For some specific apphications of this doctrine, see In re Schneider, 9 Bankr. 488 (N.D. Cal. 1981); In re Falck, 12 Bankr. 835 (Bankr. C.D. Cal. 1981).

63. See, e.g., In re Locarno, 23 Bankr. 622 (Bankr. D. Md. 1982). While the court did state that state exemption laws are only invalid to the extent of actual conflict, id. at 631-32, the court ruled that Maryland's exemption law was invalid because it allegedly violated "the avowed pohicy of the Congress in enacting the Bankruptcy Code of granting to all debtors a 'fresh start.' "Id. at 630. See also In re Smith, 23 Bankr. 708, 709 (Bankr. D. Md. 1982); In re Parrish, 19 Bankr. 331 (Bankr. D. Colo. 1982); In re Balgemann, 16 Bankr. 780 (Bankr. N.D. Ill. 1982).

64. 1898 Act, supra note $13, \S 6$. 
The courts correctly construed this language to mean that Congress had deferred to the state exemption laws. ${ }^{65}$ As a result, a debtor could exempt property from distribution in bankruptcy if the property was exempt from creditors under the nonbankruptcy law of the debtor's domicile at the time the petition in bankruptcy was filed. In Hanover National Bank v. Moyses, ${ }^{66}$ the Supreme Court upheld this deference to state law, despite claims that such deference violated the uniformity clause of the constitution. ${ }^{67}$

When the 1898 Act did alter the substantive exemption rights of the debtor, it did so explicitly. In California, for example, state courts held that a debtor could convey property in order to defeat creditors and preserve a homestead exemption on the property when creditors sought to recover it in nonbankruptcy collection proceedings. ${ }^{68}$ The 1898 Act, however, provided that no exemption "shall be made out of the property which a bankrupt transferred or concealed and which is recovered."69 The bankruptcy courts ruled that the 1898 Act prohibited claiming such property as exempt in bankruptcy, notwithstanding the conflicting state law. ${ }^{70}$ Thus, under the 1898 Act, the courts held that "exemptions, unless expressly limited by the bankruptcy law, are creatures of the law of the state in which the bankrupt hives."71

The 1898 Act's longstanding deference to state exemption laws was defended vociferously at congressional hearnigs leading to the

65. See, e.g., Smalley v. Laugenour, 196 U.S. 93, 97 (1905); Grenz Super Value v. Fix, 566 F.2d 614, 615 (8th Cir. 1977); Monson v. First Nat'1 Bank, 497 F.2d 135, 137 (5th Cir. 1974); Philips v. C. Palomo \& Sons, 270 F.2d 791, 793 (5th Cir. 1959).

66. 186 U.S. 181 (1902).

67. The Court ruled:

We ... hold that the system is, in the constitutional sense, uniform throughout the United States, when the trustee takes in each State whatever would have been available to the creditors if the bankrupt law had not been passed. The general operation of the law is uniform although it may result in certain particulars differently im different States. Id. at 190 .

68. See, e.g., Montgomery v. Bullock, 11 Cal. 2d 58, 77 P.2d 846 (1938).

69. 1898 Act, supra note $13, \S 6$.

70. See, e.g., Gardner v. Johnson, 195 F.2d 717 (9th Cir. 1952). The current Code also contains a similar provision to that quoted supra in text accompanying note 69. 11 U.S.C. \& 522(g) (1982). This discussion of fraudulent conveyances under the 1898 Act illustrates that when the 1898 Act superseded state law, it did so explicitly, and that courts could generally apply these rules rather easily. This is not to suggest that the exeinption provision under the 1898 Act was free of hitigation. The bankruptcy courts were often forced to interpret the archaic and ambiguous state exemption laws. See authorities cited supra note 22, passim (discussing the difficulties in applying the state exemption laws).

71. Kilgo v. United Distribs., 223 F.2d 167, 169 (5th Cir. 1955) (enuphasis added). In one short-lived anomaly, several courts had held that the trustee could use the "strong arm" power, see supra note 52, to defeat a claimed exemption if, on the date of bankruptcy, a creditor could have obtamed a hen effective against the exemption prior to bankruptcy. See, e.g., England v. Sanderson, 236 F.2d 641 (9th Cir. 1956). This doctrime was overruled in Lewis v. Manufacturer's Nat'1 Bank, 364 U.S. 603 (1961). 
1978 reform of the bankruptcy law. ${ }^{72}$ Witnesses at these hearings questioned the need for uniform exemptions and argued that the states should remain free to adjust exemption levels so as to balance the competing local interests of creditors and debtors. ${ }^{73}$ The House bill permitted the debtor to choose between a slate of exemptions in the Code and the exemptions of the debtor's state of domicile. ${ }^{74}$ The Senate bill preserved state autonomy over exemptions. ${ }^{75}$ Thus, both houses of Congress separately rejected an exclusive and uniform bankruptcy exeinption list. In view of this fact, ${ }^{76}$ the legislative compromise which led to the opt-out provision does not appear as "bizarre"77 as commentators have suggested. Congress simply gave the states the clroice whether to allow their residents to select the Code's exemptions or state exemptions. This victory for state control over the role of state exemption laws in bankruptcy came at the expense of debtor control over exemption selection. ${ }^{78}$

The opt-out provision of the Code preserves the deference to state law that existed under the 1898 Act. Where a state clrooses to opt out, the bankruptcy court must apply the opt-out state's exemption law. Like the former act, the Code im effect incorporates tlie exemption laws of the various states into the substantive provisions of federal bankruptcy law. ${ }^{79}$

72. Bankruptcy ACt Revision: Hearings on H.R. 31 and H.R. 32 Before the Subcomm. on Civil and Constitutional Rights of the House Comm. on the Judiciary, 94th Cong., 1st \& 2d Sess. (197576) [hereinafter cited as House Hearings; The Bankruptcy Reform Act: Hearings on S. 235 and S. 236 Before the Subcomm. on Improvements in Judicial Machinery of the Senate Comm. on the Judiciary, 94th Cong., 1st Sess. (1975).

73. See stateinent of Vern Countryman, House Hearings, supra note 72, at 358 ("I know there is going to be a lot of opposition in States like Texas and California, where the exemptions are generous . . . ."); statement of Robert Ward, House Hearings, supra note 72, at 1256 ("The present system has been working well in California, and creditors regulate the extention [sic] of credit based on this system. Thus exemptions should be a local matter and the law left as it is.").

74. H.R. 8200, 95th Cong., 1st Sess., 123 CoNG. REC. 35,642 (1977) [hereinafter cited as House bill]; HOUSE REPORT, supra note 15, at 126, reprinted in 1978 U.S. CODE CONG. \& AD. NEws at 6087.

75. S. 2266, 95th Cong., 2d Sess. (1977) [hereinafter cited as Senate bill]; S. REP. No. 989, 95th Cong., 2d Sess. 6 (1977), reprinted in 1978 U.S. CODE CONG. \& AD. NEws 5787, 5792 [hereinafter cited as SENATE REPORT].

76. It is not entirely clear that scholars who have attacked the opt-out provision have remembered this fact. See, e.g., Aaron, supra note 25, at 183-84 (discussing the legislative history but failing to inention that both houses separately rejected an exclusive federal exeinption hist).

77. Id. at 183.

78. Thus, the opt-out compromise was a defeat of debtor control, not federal control over exemptions. The proponents of an exclusively uniforn federal exemption plan had already lost the battle for federal control.

79. See, e.g., cases cited supra note 8. Professor Stern suggested in 1980 that the Bankruptcy Code may not incorporate state exemption laws into the federal bankruptcy law to the same extent as did the 1898 Act. Stern, State Exemption Law in Bankruptcy: The Excepted Creditor as a Medium for Appraising Aspects of Bankruptcy Reform 33 RUTGERS L. REv. 70, 93-103 (1980). The case law has not supported this prophecy. The disagreement among the courts has not centered 
However, unlike the former act, the Bankruptcy Code does not specify how its nonexemption provisions affect the debtor's right to claim the exemptions that are provided under state law. The opt-out provision of the current Code merely permits the states to "not . . . authorize" the Code's exemptions. ${ }^{80}$ Further, the three categories of the Code provisions-the facilitating provisions, the trustee's sale power, and the Code's exemptions ${ }^{81}$ - that could substantially alter the effect of state laws do not mdividually state whether they supersede state exemption laws. ${ }^{82}$ These provisions did not exist under the former act but were added as part of the bankruptcy law reform in 1978 . Thus, the language of the Code presents an ambiguity that is new to the law of bankruptcy and that, unlike the 1898 Act, must be resolved by statutory interpretation. This distinction between the Code and the former act suggests that the proliferation of litigation accompanymg state opt-out law has been caused by two factors: first, the Code's silence on the critical question whether its provisions affect state exemption laws; and second, the existence of provisions that did not appear in the former bankruptcy law, and that are ambiguous concerning their impact upon state exemption laws.

\section{B. A Framework for Resolving Conflicts}

The foregoing comparison of the Code and the former bankruptcy act yields insight into how courts should resolve conflicts involving exemptions in opt-out states. Under the 1898 Act, the courts simply examined the state law of the debtor's domicile to ascertam the debtor's exemption rights. Simce the Act explicitly stated that its provisions did not affect state exemption laws, and was meticulously drafted to preserve the debtor's state exemption rights, ${ }^{83}$ the courts did not have to consider the preclusive effect of the Act upon state exemption laws; when the courts ascertained the debtor's exemption rights under state law, their analysis was complete. The current Bankruptcy Code also permits states to write the substantive exemption law by opting out of the Code's exemptions. However, the Code does not explicitly state that its nonexemption provisions do not affect these rights. This suggests that in resolving conflicts between exemptions in opt-out states and Code provisions, a court must engage in two levels of analysis.

around the degree to which state exemption law is incorporated into bankruptcy, but around the degree to which specific provisions of the Code supersede state exemption laws and affect the substantive exemption rights of debtors.

80. 11 U.S.C. \& 522 (b)(1) (1982).

81. See supra text accompanying notes 47-57.

82. 11 U.S.C. $\$ \S 522(\mathrm{f}), 363(\mathrm{~h}), 522(\mathrm{~d})$ (1982).

83. For example, the trustee in bankruptcy under the 1898 Act did not acquire title to exempt property. See Countryinan, supra note 6, at 437-75. 
First, the court must ascertain the debtor's rights under the opt-out state's exemption law. This includes an examination of the construction given to these statutes by state courts, and, if the courts are divided, a prediction, in accordance with the principles underlymg Erie R.R. v. Tompkins, ${ }^{84}$ of how the state's highest court would interpret the state law. ${ }^{85}$ This examination of state law is necessary because the Bankruptcy Code, like the 1898 Act, allows the state to determine the debtor's exemption rights. Unless the provisions of the Code supersede a particular state exemption law, the state law will determine the debtor's exemption rights. Hence, in this respect, the Code is no different from the 1898 Act.

Second, the court inust determine whether Congress intended certain provisions of the Code-the facilitating provisions, the trustee's sale power, and the Code's exemptions - to affect the operation of state exemption laws in bankruptcy and to alter the substantive rights provided in these state laws. ${ }^{86}$ The courts inust engage in this second level of analysis because the Bankruptcy Code, unlike the $1898 \mathrm{Act}$, does not state a general rule regarding the effect of the Code's provisions upon opt-out state exeinption laws.

Congress has, however, explicitly incorporated the exemption laws of the opt-out states into the federal bankruptcy law. ${ }^{87}$ Therefore, the courts must conclude that Congress has intended to defer to the state exemption law in bankruptcy, unless it is shown that Congress intended these particular provisions of the Code to limit the discretion it granted to the states. Those courts that have held that the opt-out provision gives the states coinplete authority over exeinptions ${ }^{88}$ have failed to recognize that while Congress gave the states authority to set exemption levels, Congress may have intended to regulate state authority over

84. 304 U.S. 64 (1938).

85. The courts have held that the bankruptcy courts must follow the rule of West v. AT\&T, 311 U.S. 223, 237-38 (1940), which provides that a federal court must apply the state appellate court's interpretation of the state law, "unless it is convinced by other persuasive data that the highest court of the state would decide otherwise." Id. at 237. See, e.g., In re Schneider, 9 Bankr. 488 (N.D. Cal. 1981) (correctly rejecting In re Bonant, 1 Bankr. 335 (Bankr. C.D. Cal. 1979)); In re Newhouse, 4 BANkR. CT. DEC. (CRR) 744 (Bankr. N.D. Ohio 1978). Where, however, the state law is manifestly ambiguous and the state courts are divided, the federal court may interpret the state exemption law so as to comport with the purposes of the bankruptcy law. See e.g., Vought v. Kanne, 10 F.2d 747 (8th Cir. 1926), cert. denied, 275 U.S. 574 (1927).

86. See International Shoe Co. v. Pinkus, 278 U.S. 261 (1929). In Pinkus, the Supreme Court struck down an Arkansas insolvency statute, stating that "the intention of Congress is plain. . . . Congress did not intend to give insolvent debtors seeking discharge . . . [a] choice between the relief provided by the Bankruptcy Act and that specified in state insolvency laws." Id. at 265. For cases which have atteinpted, though largely unsuccessfully, see infra note 89 , to determine Congress' intent regarding these provisions of the Code, see, e.g., In re Baxter, 19 Bankr. 674, 675-76 (Bankr. 9th Cir. 1982); In re Meadows, 9 Bankr. 882, 883-84 (Bankr. N.D. Ga. 1981).

87. 11 U.S.C. $\$ 522(b)(1)$ (1982).

88. See cases cited supra note 62. 
exemptions through these three categories of Code provisions. Since Congress has plenary authority to legislate bankruptcy laws, one can only measure the degree of state authority over exemptions in bankruptcy by examining congressional intent. ${ }^{89}$

A number of courts have attempted to apply the test articulated by the Supreme Court in Perez $v$. Campbell ${ }^{90}$ to exemption cases. ${ }^{91}$ Perez involved an Arizona statute that provided that the discharge in bankruptcy of an automobile accident liability did not discharge the debt. The Court ruled that to determine whether a state and a federal law conflict, it must examine the construction given to both laws ${ }^{92}$ and ask whether the state law " stands as an obstacle to the accomplishment and execution of the full purposes and objectives of Congress." "93 The Court held that since Congress provided debtors with a discharge of automobile accident habilities, the Arizona law conflicted with the bankruptcy law and was unconstitutional. ${ }^{94}$ The Court simply compared the nonexemption state law in Perez with the discharge provision of the Bankruptcy Act; since Congress had provided for the discharge of automobile claims, the Court could determine rather easily that the state law violated Congress' "purposes and objectives."

It is far more difficult, however, to analyze conflicts between state exemption laws and the provisions of the Code. In these cases, a court must compare two provisions of the Code: the provision of the Code and the state exemption law, incorporated into the federal bankruptcy law by virtue of the opt-out provision. Although, as one court has suggested, a miserly state exemption law may violate Congress' "fresh start" policy, ${ }^{95}$ such a state exemption law comports with another important goal of Congress: encouraging diversity among the states by

89. A number of courts have attempted to determine Congress' intent by examining the legislative history of the Code. See, e.g., Cheeseinan v. Nachman, 656 F.2d 60 (4th Cir. 1981); In re Baxter, 19 Bankr. 674 (Bankr. 9th Cir. 1982). These cases, however, share a common defcct. They cite parts of the legislative history that were written before Congress imserted the opt-out provision into the Code. These courts have failed to ask whether Congress intended to permit the states to negate these various provisions of the Code, or, if not, whether the opt-out provision alters the way that these provisions operate. Such an inquiry yields a proper interpretation of how various Code provisions should affect debtors' exemption rights. See infra text accompanying notes 153-69 (discussing how the opt-out provision affects the operation of $\$ 522(\mathrm{~m})$, the joimt debtor provision). For an excellent illustration of how the courts should analyze issues involving the preemptive effect of the Code upon state exemption laws in the manner suggested in this Comment, see In re Neiheisel, 32 Bankr. 146 (Bankr. D. Utah 1983) (analyzing both the Code and the state exemption law, but in the reverse order of that suggested in this Comment).

90. 402 U.S. 637 (1971).

91. See, e.g., In re Goering, 23 Bankr. 1010, 1013 (Bankr. N.D. Ill. 1982); In re Locarno, 23 Bankr. 622, 629 (Bankr. D. Md. 1982).

92. Perez, 402 U.S. at 644.

93. Id. at 649 (quoting Hines v. Davidowitz, 312 U.S. 52, 67 (1941)).

94. Id. at 644-56.

95. In re Locarno, 23 Bankr. 622, 630 (Bankr. D. Md. 1982). 
permitting the states to write the exemption laws. ${ }^{96}$ Analyzing conflicts between the Code and state exemption laws in terms of Congress' general "purposes and objectives" thus yields little imsight into the validity of these laws because Congress had dual purposes in drafting the exemption provision of the Code. ${ }^{97} \mathrm{~A}$ court can only determine whetlier a provision of the Code affects a state exemption law by examining Congress' specific purposes and objectives in passing that specific provision of the Code. Congress has implicitly required this analysis by incorporating the state exemption provisions of the opt-out states into the Code. The courts must examine the legislative history of the Code, ${ }^{98}$ as well as its overall statutory sclieme,"99 to ascertain which "section" of the Code-the state exemption law or the specific provision of the Code-Congress intended should determine the debtor's exemption riglits.

\section{III}

\section{CALIFORNia's Homestead EXemption LaW}

The foregoing discussion has provided a general frainework for determining whether the three categories of Code provisions affect the exemption riglits of debtors im opt-out states. This Cominent will apply that analytical framework to California's homestead law to determine what the outcome of sucl an analysis should be and to illustrate how this outcome can affect the operation of an actual exemption statute. This Part examines the workings of California's lomestead exemption law and the construction that the California courts have given this law. Part IV then analyzes whether the three categories of Code provisions either enlarge or narrow the riglits of debtors in California to claim the liomestead exemption.

The California Legislature has recently revised the liomestead law. Though the primiary purpose of this revision was to simplify the procedures for claiming homestead exemptions, ${ }^{100}$ the legislature made several substantive changes in the liomestead law. Many of these changes are likely to be the subject of bankruptcy litigation im the near future.

96. See infra text accompanying notes 224-26 (discussing this goal).

97. See Vukowich, supra note 16, at 774 ("Each chamber's position becaune realizable, depending on the actiou of state legislatures. The Senate position would prevail in the states that enacted legislation to deny their residents the alternative bankruptcy exeinption. The House position would be realized in states that did not enact 'opt out' legislation.").

98. See, e.g., In re Cunha, 1 Bankr. 330, 332 (Bankr. E.D. Va. 1979) (noting the importance of legislative history).

99. See, e.g., Lewis v. Manufacturers Nat'1 Bank, 364 U.S. 603 (1961) (examining the statutory scheine to resolve an issue).

100. The reform was proposed by the California Law Revision Commission. In a pamphlet it published, the Commission discussed the complex procedures that plagued the former law. CALIfornia LaW Revision Commission, 1982 CREDitoR's Remedies Legislation 1093 (1982). 
In addition, a number of the provisions carried over from the old law have already been heavily litigated in bankruptcy. Of course, in any given bankruptcy litigation, the court need only consider those provisions of the state law relevant to the debtor's case. This Part will only consider those provisions of California's homestead exemption law that may be affected by the three categories of Code provisions mentioned earlier.

\section{A. The Homestead Protection}

California's lomestead exemption law provides protection for a portion of the equity im the debtor's home against creditors who seek satisfaction by forced sale of the home. ${ }^{101}$ The homestead law provides this protection through its two principle provisions-the "minimum bid"102 and the "proceeds exemption."103 The minimum bid requirement prohibits a court from ordering the sale of a home unless the sale bid exceeds the amount of the exemption to which the debtor is entitled plus all liens and encumbrances on the home. If the court orders the sale of the home, the proceeds exemption allows the debtor to retam the exempt amount, in the forn of cash, free from the claims of creditors for a period of six months following the sale. The homestead exemption thus perforns two functions corresponding to the two provisions: first, it permits a debtor "to hinder and defeat the claims of his creditors" by making forced sale more difficult; ${ }^{104}$ and second, it gives the debtor freedom to " substitute one family home for another without losing his exemption" "105 should forced sale occur. The California courts have often stated that the homestead law is to be liberally construed in favor of the debtor. ${ }^{106}$

California allows the homeowner to choose between two types of homestead exemptions: the automatic and the declared homestead. ${ }^{107}$ The automatic homestead attaches to the principal dwelling of each

101. Enforcement of Judgments Law, ch. 1364, \& 2, 1982 Cal. Stat. 5070, 5163-69. For analysis of California's homestead law prior to 1983, see Adams, Homestead Legislation in California, 9 PAC. L.J. 723 (1978); Comment, Creation of the Homestead and Its Requirements, 26 CALIF. L. REV. 241 (1938). A number of states exempt a portion of acreage from forced sale. See, e.g., Okla. Const. art. XIl, § 1; Kan. Stat. AnN. § 60-2301 (Supp. 1983); OkLA. STat. ANN. tit. 31 , $\S \S 1,2$ (West Supp. 1983); id. \& 5 (West 1976) (rural acreage).

102. Cal. Civ. Proc. Code $\$ 704.800$ (West Supp. 1984).

103. Id $\S \S 704.720(\mathrm{~b}), 704.960$.

104. Viotti v. Giomi, 230 Cal. App. 2d 730, 737, 41 Cal. Rptr. 345, 349 (1964).

105. Ortale v. Mulhern, $58 \mathrm{Cal}$. App. 3d 861, 864, $130 \mathrm{Cal}$. Rptr. 277, 279 (1976) (quoting

Thorsby v. Babcock, 36 Cal. 2d 202, 205, 222 P.2d 863, 865 (1950)).

106. See, e.g., Lee v. Brown, 18 Cal. 3d 110, 553 P.2d 1121, 132 Cal. Rptr. 649 (1976).

107. The homestead statute does not actually label this first exemption statute "automatic homestead." In fact, the statute does not label it at all. See CAL. Civ. Proc. Code $\$ 704.710$ (West Supp. 1984). The label "automatic homestead" best describes its distinguishing feature. 
hoineowner in the state; the houneowner need not file any record to obtain its protection. ${ }^{108}$ The declared hoinestead, in contrast, does not attach autonnatically, but requires the hoineowner to record a declaration in the office of the county recorder where the principal dwelling is located. ${ }^{109}$ When the hoineowner files this declaration, the provisions of the declared homestead replace those of the automatic homestead.

While the autonatic and declared homesteads differ in several important respects, they are identical in both the amount of protection they provide and the types of hens against which they protect. California allows the holder of an autonnatic or declared homestead to claim a $\$ 30,000$ exemption, or a $\$ 45,000$ exemption if the debtor or the debtor's spouse is sixty-five years of age or older or if there is at least one member of the debtor's "family unit" "who owns no interest in the homestead or whose only interest in the homestead is a community property interest with the judgnient debtor." 110 The counbined homestead exemption of spouses inay not exceed $\$ 45,000 .{ }^{111}$

Both the automatic and declared exemptions are ineffective against the claims of two types of lienholders. First, the homestead exemption does not operate against the holders of consensual liens. ${ }^{112}$ The rationale for this immunity from exemption is that the consensual lienholder was instrumental in helping the debtor acquire the home. It would be unfair to prevent such creditors froun obtaining full satisfaction when the debtor defaults. Second, the hoinestead exeniption does not operate against liens recorded before the debtor acquired his hoine. To receive homestead protection, the debtor or the debtor's spouse must actually reside at the home on the date the lien was recorded. ${ }^{113}$ This limitation precludes a debtor from purchasing a hoine or moving into a dwelling for the sole purpose of defeating creditors. ${ }^{114}$

The automatic and declared homesteads differ in the protection

108. Id. $\$ 704.710(\mathrm{c})$. The predecessor of the automatic homestead was the dwelling house exemption. See id. $\$ 690.31$ (West 1980) (repealed 1983):

109. Id. $\S \S 704.920,704.930$ (West Supp. 1984).

110. Id. $\$ 704.730(\mathrm{a})$; see also id. $\$ 704.710$ (b) (defining "family unit"). This means that where a debtor is married, has no children, and owns the hoine as a joint tenant, the debtor is limited to a $\$ 30,000$ exemption. The assembly comment to $\$ 704.730$ (2)(b) states that this section "makes clear there is no imcreased exeinption if the members of the family unit also own interests in the homestead (except a community property. interest)." Cal. Assembly Leglslative Comment to CAL. CIv. Proc. Code $\$ 704.730$ (a)(2)(b) (West Supp. 1984).

111. Cal. Civ. Proc. CODE $\S 704.730$ (b) (West Supp. 1984).

112. Id. $\$ 703.010(\mathrm{~b})$.

113. Id. $\$ 704.710$ (c). The California courts have traditionally allowed few exceptions to this rule. See, e.g., Ellsworth v. Marshall, 196 Cal. App. 2d 471, 16 Cal. Rptr. 588 (1961) (strict application of this rule). For an example of an exception, see Michelman v. Frye, 238 Cal. App. 2d 698, 48 Cal. Rptr. 142 (1965).

114. See Cal. Senate Legislative Comment to Cal. Civ. Proc. Code $\$ 704.710$ (c) (West Supp. 1984). 
that they provide against liens which overencuinber the fainily home. For exainple, suppose that a debtor's hoine has a market value of $\$ 145,000$ and is subject to a $\$ 100,000$ lien which was recorded after the debtor acquired the home. The debtor has not filed a hoinestead declaration and is entitled to a $\$ 45,000$ automatic exemption. A second creditor then records a $\$ 50,000$ lien. The automatic homestead provision permits the second lien to attach to the home and overencumber the debtor's property to the extent of $\$ 50,000 .{ }^{115}$ Since the minimum bid requires that buyers satisfy all the liens on the property, the second hen lias the practical effect of "landlocking" the debtor; no rational purchaser would bid $\$ 195,000$ for a $\$ 145,000$ hoine. While this feature of the automatic hoinestead exemption prevents forced sale of the hoine, it also largely prevents the debtor from substituting one family hoine for anotlier.

The declared homestead, in contrast, does not landlock the debtor. Section 704.950 of the California Code of Civil Procedure provides that a judgment lien will not attach to a declared lomestead unless there is a surplus in value over the exemption plus all liens on the property at the time the judginent lien was created. ${ }^{116}$ The second lien in the foregoing exainple would not attacls to the lioinestead; bidders at a forced sale would only be required to cover the $\$ 145,000$ and would receive a fair return on their bids. By allowing the debtor to sell his home easily, the declared homestead better serves the twin functions of the homestead law: freedom to purchase a new home and reasonable protection agamst forced sale. ${ }^{117}$

115. Cal. Crv. Proc. Code $\$ 704.950$ (c)(2) (West Supp. 1984). Under the former homestead law, a judgment creditor could not obtain a lien on the liome if the debtor lad already filed a lomestead declaration. Swearingen v. Byrne, 67 Cal. App. 3d 580, 584-85, 136 Cal. Rptr. 736, 739 (1977).

116. Cal. Civ. Proc. Code $\S 704.950$ (c) (West Supp. 1984).

117. The declared homestead, however, does appear to create an unfortunate anomaly. Suppose that a debtor's lome has a market value of $\$ 145,000$; the debtor files a homestead declaration and is entitled to a $\$ 45,000$ exemption. On March 1, a creditor files a $\$ 100,000$ judgment lien. On March 2, a second creditor records a $\$ 10,000$ lien. Since the second lien overencumbers the property, $\S 704.950$ provides that the lien does not attach to the lomestead. Suppose that two years later the market value of the home has risen to $\$ 155,000$. A third creditor then files a $\$ 10,000$ lien. Since there is an equity at the time the third creditor files the lien, the lien attaches to the property. This creates an absurd result; the second judgment creditor receives no satisfaction. This contradicts the fundamental principle that an earlier lieuor has absolute priority over a later lienor. See id. $\$ \S 697.380,703.050$. A lien, by definition, gives priority to those who are first in time. Further, $\$ 704.950$ forces courts to undertake the virtually impossible task of determining retrospectively the value of the liome at the time the creditor recorded the lien. To avoid this impossible task and unfortunate result, the legislature sliould amend this section to provide that where there is a surplus above the exemption at the time of sale, the surplus inures to the beuefit of lienors who are first in time. Until this reform occurs, however, the bankruptcy courts are bound by this law. 


\section{B. Homestead Exemption On Undivided Interests}

One of the inost difficult problems involving California's homestead exemption, arising in state as well as bankruptcy cases, is the right of debtors to claim exemptions where they hold interests in the home as joint tenants or tenants in common. In the leading case of Schoenfeld v. Norberg, ${ }^{118}$ the California Court of Appeal ruled upon three major issues that have arisen in this area: first, whether the nature of the debtor's holding is relevant to the right of the debtor to claim a hoinestead exemption; second, whether the court should apportion the value of the exemption when the debtor owns less than a full interest in the home; and third, whether bidders at a sale of the onehalf interest must cover the total value of all consensual hens on the property or just one-half of the hens.

In Schoenfeld, the creditor sought to satisfy a inoney judgment against a debtor by selling the interests of both the debtor and his wife in their home. The hoine was appraised at $\$ 35,000$. The trial court ruled that simce the value of the home exceeded the joint encuinbrances $(\$ 9,099)$ and the hoinestead exeinption (at the time, $\$ 12,500)$, the home could be sold to satisfy the creditor's judgment. The trial court permitted the sale of the property without determining whether the debtor owned a joint tenancy interest in the hoine or held the property as a community interest. ${ }^{119}$ On appeal, the Schoenfeld court reversed and made three significant rulings.

First, the court ruled that since the creditor had only obtamed judginent against the debtor, the trial court would have to determine whether the home was held in joint tenancy or as community property. If the home was held in community property, the entire property could be sold in satisfaction of the creditor's judgment because a nondebtor spouse's interest in community property is subject to levy and sale for the debtor spouse's debts. ${ }^{120}$ If, however, the property were held in joimt tenancy, "the wife's interest, being her separate property [would not be] hable for the husband's debt; in that event, only the husband's interest [could] be sold." 121

Second, the court ruled that even if the trial court on reniand found that the property was held in joint tenancy so that only a half interest could be sold, the trial court would still be required to allot

118. 11 Cal. App. 3d 755, 90 Cal. Rptr. 47 (1970).

119. Id. at 759-60, 90 Cal. Rptr. at 49-50.

120. Id. at 760, 90 Cal. Rptr. at 49-50; see also In re Marriage of Smaltz, 82 Cal. App. 3d 568, 147 Cal. Rptr. 154 (1978).

121. Schoenfeld, 11 Cal. App. 3d at 760, 90 Cal. Rptr. at 49. California has codified this part of the Schoenfeld opinion. See CAL. Civ. Proc. CodE $§ 704.820$ (a) (West Supp. 1984). 
the debtor spouse a full homestead exemption. ${ }^{122}$ Purchasers at the execution sale would have to cover the full $\$ 12,500$ exemption. The Schoenfeld court thus refused to apportion a homestead exemption where a debtor owns only a part interest $\mathrm{m}$ the home.

By giving a part owner a full exemption, the Schoenfeld rule appears to violate the principle that a husband and wife may only claim one full exemption per family home. ${ }^{123}$ However, permitting a coowner to claim a full exemption does not mean there will be two exemptions. Schoenfeld only permitted a debtor to claim a full exemption before a forced sale occurs. Once the property is sold, the exemption no longer exists. ${ }^{124}$ Thus, the full exemption "floats" between the jomt tenants' interests until the bids cover the full exemption. As stated by the court in In re Bartlett, ${ }^{125}$ "[ $[\mathrm{t}]$ he homestead exemption is not used up each time it is asserted as a shield, but rather, only when the property is sold. If a sale can be forced, then the exemption is allocated to the judgment debtor's interest and no longer 'floats' between the joint interests. . . ."126 The proper resolution of the apportionment question should not depend upon whether each debtor has claimed a full exemption.

The Schoenfeld court's rejection of apportionment was proper for two far more important reasons. First, Califorma's homestead statute was then, and is now, ambiguous on the issue of apportionment. ${ }^{127}$ The courts have held that the homestead exemption must be liberally interpreted; ${ }^{128}$ the Schoenfeld court followed that directive. Second, the rule protects the "innocent" nondebtor cotenant. The value to the

122. Schoenfeld, 11 Cal. App. 3d at 763-64, 90 Cal. Rptr. at 52-53.

123. In re Rauer's Collection Co., 87 Cal. App. 2d 248, 196 P.2d 803 (1948). In Rauer, the court held that the homestead exemption does not apply to the particular interest of the homesteading party, but to the property itself, and that only one hounestead exeinption inay be claimed on the property. Hence, the court ruled that where a debtor owns only a portion of the property, the debtor may not claim a full homestead exemption. Id. at 262-63, $196 \mathrm{P} .2 \mathrm{~d}$ at $811-12$.

124. Strangman v. Duke, 140 Cal. App. 2d 185, 190, 295 P.2d 12, 16-17 (1956). In Strangman, the court held that where a debtor/joint tenant declares a homcstead exeinption, the debtor is entitled to a full exemption:

The result of this is that if the husband's creditors first pursue the statutory incthod of enforcing an execution he gets the benefit of the exeinption, or if the wife's creditors move first she gets it; once the property is sold the homestead is gone and the question of apportionment of the exeinption has exhausted its practical importance.

Id. at 190,295 P.2d at $16-17$.

125. 24 Bankr. 605 (Bankr. 9th Cir. 1982) (properly interpreting Strangman and applying that holding to a bankruptcy case).

126. Id. at 607 .

127. California's new homestead law does not remedy the ambiguity of its predecessor. While the current law states that a husband and wife may not claim inore than one $\$ 45,000$ hoinestead between them, see CAL. CIV. Proc. CoDE $\S 704.730$ (b) (West Supp. 1984), the arguinent made in Strangman v. Duke, 140 Cal. App. 185, 190, 295 P.2d 12, 16-17 (1956), remains valid; each cotenant does not receive a full exemption, but can assert the exeinption until sale oceurs.

128. See, e.g., Lee v. Brown, 18 Cal. 3d 110, 553 P.2d 1121, 132 Cal. Rptr. 649 (1976). 
creditor of obtaining a part interest in a home may be minimal. But the disruption to the nondebtor of being forced to share an interest with a creditor is likely to be great. By forcing creditors to cover the entire exemption, the $S c h o e n f e l d$ rule strikes a balance between competing interests. On the one hand, it makes forced sale inore difficult, thereby protecting the nondebtor from an unnecessary and marginally beneficial forced sale. On the other hand, it does not immunize those interests from forced sales altogether. Though the California Supreme Court has never ruled on the issue of apportionment, it has commented favorably on the hiberal tenor of the Schoenfeld opinion, ${ }^{129}$ and the Schoenfeld court's ruling on apportionment probably represents the controlling authority in California. Consequently, absent a contrary provision in the Code, ${ }^{130}$ a bankruptcy court would be forced to apply this rule in California. ${ }^{131}$

Finally, the Schoenfeld court ruled that the husband's interest in the hoine could not be sold unless the bids at the execution sale covered the full value of all joint encnmbrances on the property. ${ }^{132}$ Even though a purchaser at an execution sale would acquire only a one-half interest, he would have to cover the entire mortgage. The Schoenfeld court recognized that this rule would make forced sales virtually impossible. The court reasoned, however, that since the encumbrance was jointly given by the husband and wife, the inortgagee could foreclose upon the entire property. If the court apportioned the encuinbrances and discharged only half of them, the mortgagee "could still go against the imterest of the purchaser to obtain satisfaction of the other

129. Caito v, United Cal. Bank, 20 Cal. 3d 694, 701, 576 P.2d 466, 470, 144 Cal. Rptr. 751, 754-55 (1978); Lee v. Brown, 18 Cal. 3d 110, 113, 553 P.2d 1121, 1122, 132 Cal. Rptr. 649, 650 (1976).

130. Such a provision exists. See infra text accompanying notes 174-207.

131. There is httle persuasive data that California's highest court would reject the Schoenfeld court's rulings. See supra note 85 . Both Schoenfeld and Strangman (the latter implicitly) rejected the holding in In re Rauer's Collection Co., 87 Cal. App. 2d 248, 196 P.2d 803 (1948). Further, the United States Supreme Court has implied that when a state's highest court has approved of a ruling, the holding is binding upon the federal court applying state law. Gooding v. Wilson, 405 U.S. 518, $526 \mathrm{n.4}$ (1972). The bankruptcy courts have generally applied Schoenfeld in bankruptcy cases. See In re Sclineider, 9 Bankr. 488 (N.D. Cal. 1981) (correctly rejecting In re Bonant, 1 Bankr. 335 (Bankr. C.D. Cal. 1979) because California's highest court would probably approve of Schoenfeld, see supra note 85); In re Miles, 35 Bankr. 52 (Bankr. E.D. Cal. 1983). For a criticism of the second rule of Schoenfeld, see Adams, supra note 101, at 728, 738.

132. Schoenfeld v. Norberg, 11 Cal. App. 3d 755, 766, 90 Cal. Rptr. 47, 53-54 (1970). To illustrate, suppose a debtor and his wife own a home as joint tenants. The house is valued at $\$ 200,000$ and is jointly encumbered by a $\$ 100,000$ trust deed and a $\$ 5,000$ hen. A creditor of the husband seeks to sell his interest in the home. The second rule of Schoenfeld states that bidders must cover the $\$ 45,000$ exeinption to sell the husband's imterest. The third rule states that bidders must also cover the full $\$ 100,000$ trust deed and the $\$ 5,000$ hen. Purchasers must bid $\$ 150,000$ for a one-half interest valued at only $\$ 100,000$; no rational purchaser would so bid. 
half of the debt."133 To avoid this result, the court held that bidders must cover all liens and encumbrances. ${ }^{134}$

This analysis of California's homestead law indicates that Califorma provides its lomeowners witl strong protections agamst forced sale. Owners of joint tenancies im particular receive special protection where a creditor lias obtamed a judgment against only one joint tenant. The only significant limitation on a debtor's ability to protect against a forced sale of a lome is that the debtor may not claim exemptions against mortgages and preexistimg liens.

\section{IV \\ Resolving the Conflicts: California's Homestead LAW AND THE CODE'S PROVISIONS}

Part IV examines low the Bankruptcy Code affects the right of debtors in bankruptcy to claim exemptions. Specifically, this Part applies the framework developed in Part II to resolve the conflicts between California's homestead law and the Bankruptcy Code.

\section{A. The Homestead Exemption and the "Facilitating" Provisions}

\section{The Avoidance Provision}

The "avoidance" provision of the Bankruptcy Code, section $522(\mathrm{f}),{ }^{135}$ presents perhaps the most difficult issue imvolving the effect of the Code upon California's homestead exemption law. The issue arises im the following manner: A creditor obtains a judgment lien against the debtor and records the lien in the various counties across the state. The debtor then purchases a home and files a lomestead declaration. The lien was recorded before the debtor filed the homestead declaration and therefore, under California law, the lien is unaf-

133. Id. at $766,90 \mathrm{Cal}$. Rptr. at 54.

134. Id. Section 2912 of the California Civil Code, not cited in Schoenfeld, dictates this result. This section provides that the "partial performance of an act secured by a lien does not extinguish the lien upon any part of the property subject thereto, even if it is divisible." CAL. Civ. Code $\S 2912$ (West 1974). This provision applies to trust deeds. See Loretz v. Cal-Coast Dev. Corp., 249 Cal. App. 2d 176, 178, 57 Cal. Rptr. 188, 189 (1967). Hence, if the purchaser had only paid off laalf the encumbrance, his interest would still be subject to foreclosure.

The California Legislature should amend its homestead provision to overrule this aspect of Schoenfeld. By requiring purchasers to pay off the entire encuunbrance, this rule virtually immunizes joint tenancy interests from forced sale. "[T]he benign object of homestead statutes is to protect the home of the owner from forced sale and not to withdraw from the reach of creditors property of the debtor as a source of revenue for support of himself or family." Sherwood v. Cornfield, 216 Cal. App. 2d 364, 371, 31 Cal. Rptr. 264, 269 (1963) (emphasis in original). If the purchaser at an execution sale has paid off the pro rata value of the encumbrances on the part interest, then the purcliaser should not be liable for the co-owner's indebtedness.

135. 11 U.S.C. $\$ 522(f)(1982)$. 
fected by the homestead exemption. ${ }^{136}$ The debtor then files in bankruptcy and seeks to claim a homestead exemption in the home by making use of the Code's avoidance provision. This section provides, in part:

Notwithstanding any waiver of exemptions, the debtor may avoid the fixing of a lien on any interest of the debtor in property to the extent that such hen impairs an exemption to which the debtor would have been entitled under subsection (b) of this section, if such lien is-

(1) a judicial lien; or

(2) a nonpossessory, nonpurchase-money security interest . . . . ${ }^{137}$

Creditors, of course, object to the use of this section and argue that the state exemption law is controlling. The courts have developed two conflicting interpretations of section 522(f).

The first imterpretation finds the avoidance provision simply a procedural device that does not affect the rights of debtors to claim exeinptions in opt-out states. In In Re McManus, ${ }^{138}$ the Fifth Circuit denied a debtor's attempt to avoid a nonpossessory nonpurchase-money security interest where the debtor's state of domicile forbade the claiming of exemptions on such interests. The court reasoned that section 522(f) explicitly ties the avoidance power to the exemption provisions of section 522(b) (the opt-out provision) by stating that a debtor may only avoid a lien " "to the extent that such lien impairs an exemption to which the debtor would have been entitled under subsection (b)' of section 522." 139 The court ruled that since section 522(b) permits the states to opt out, the debtor in an opt-out state can avoid a lien only to the extent that it impairs an exemption allowed under the relevant optout law. ${ }^{140}$

Several courts liave reasoned that since Congress gave the states authority to write the exemption laws by virtue of the opt-out provision, the drafters of the Code could not have intended for section 522(f) to alter the state exemption laws. ${ }^{141}$ In Foster $v$. City Loan and Savings Company, ${ }^{142}$ the court cited Senator DeConcimi's comments on the optout provision made after House and Senate conferees liad added section 522(f) to the bankruptcy reform bill: "In the area of exemptions, it was agreed that a Federal exemption standard will be codified but that the states could at any time reject them in which case the State exeinp-

136. Cál. CIv. Proc. Code $\$ 704.710$ (c) (West Supp. 1984).

137. 11 U.S.C. $\$ 522(f)(1)(2)(1982)$.

138. 681 F.2d 353 (5th Cir. 1982).

139. Id. at 355 (quoting 11 U.S.C. $\$ 522(f)(1982)$ ).

140. Id. at 355-56; see also In re Pine, 717 F.2d 281 (6th Cir. 1983); In re Evans, 25 Bankr. 105, 110 (Bankr. N.D. Tex. 1982); In re Falck, 12 Bankr. 835 (Bankr. C.D. Cal. 1981).

141. See cases cited supra note 140.

142. 16 Bankr. 467, 469 (Bankr. N.D. Obio 1981). 
tion laws would continue to prevail." 143 The court in Foster concluded that the opt-out provision gave the states ultimate authority over exeinptions.

The second interpretation of the avoidance provision, adopted by the Bankruptcy Appellate Panel for the Ninth Circuit, is that debtors inay avoid preexisting hens, despite state law to the contrary. In In re Baxter, ${ }^{144}$ the trial court denied the debtors' claim of a hoinestead exeinption because the creditor had filed the hen before the debtors had recorded the hoinestead declaration. The appellate panel reversed, holding that the Code's legislative history supported the debtors' claim. Both the Senate and House reports on the proposed bankruptcy law stated that a debtor may utilize section $522(f)$ to "avoid a judicial lien on any property to the extent that the property could have been exenipted in the absence of the lien."145 If the hen in Baxter had not existed, the debtors certainly could have claimed a full homestead exemption. Accordingly, the court ruled that section 522(f) permitted the debtors to avoid the lien to the extent that it impaired the debtors' exemption. ${ }^{146}$

Arguably, the above quotation from the legislative history conflicts with the express language of the avoidance provision. The McManus court stated that the plain wording of the section ties the avoidance power to the rights provided under state law. This reading of section 522(f) is so obvious that the courts have overlooked another entircly plausible interpretation. The avoidance provision does not state that a debtor may avoid liens which impair an exemption to which the debtor is entitled under section 522(b). The section uses tlie words "would have been entitled." This language can be read to mean, as the legislative history suggests, that the debtor may claim the amount of exemption lie would have been allowed under the state's exemption law had the state permitted exemptions agaimst "judicial hens and nonpossessory, nonpurchase-1noney" interest. ${ }^{147}$ While the language of section

143. Id. at 469 (quoting Sen. DeConcini, 124 CoNG. REC. S17404 (daily ed. Oct. 6, 1978)); see also statement of Sen. Wallop: "In the area of exemptions, we have won an important victory for the rights of states to determine exemptions for the debtors of the states. Reduced federal exemptions will be provided by the law but States by legislature may elect not to have them apply to their debtors." 124 CoNG. REC. S17406 (daily ed. Oct. 6, 1978).

144. 19 Bankr. 674 (Bankr. 9th Cir. 1982); see also In re Maddox, 34 Bankr. 801 (Bankr. N.D. Ga. 1982) (involving a nonpossessory nonpurchase-money security interest), affd, 713 F.2d 1526 (11th Cir. 1983).

145. Baxter, 19 Bankr. at 676 (quoting HouSE REPORT, supra note 15, at 362, reprinted in 1978 U.S. CODE CONG. \& AD. NEws at 6318); see SENATE REPORT, supra note 75, at 77, reprinted in 1978 U.S. Code Cong. \& AD. News at 5862. However, it is important to note that the opt-out provision was added to the Code after this statement was made.

146. Baxter, 19 Bankr. at 676.

147. 11 U.S.C. $\$ 522(f)$ (1982). While a number of courts have disagreed with the holding in 
522(f) probably supports either interpretation, the latter coinports with the legislative history of the section. ${ }^{148}$

A close examination of the legislative history reveals that Congress did intend that section 522(f) should operate in opt-out jurisdictions. Both the Foster and McManus courts failed to inquire whether Congress intended to apply federal avoidance to opt-out jurisdictions. Both the Senate and House bills made some use of state exemption laws before Congress settled upon the opt-out coinpromise. ${ }^{149}$ The Senate bill preserved state autonomy over exeinptions. Nevertheless, the Senate bill included the same avoidance provision which ultimately appeared in the final draft, and the Senate report's comment to this provision stated that the "debtor inay avoid a judicial lien on any property to the extent that the property could have been exempted in the absence of the hen."150 Hence, the drafters of the Senate bill conteinplated that the avoidance provision would guarantee the debtor the right to clami exeinptions against liens that could not be extinguished under state law. The opt-out coinpromise inerely gave the states the choice of whether to offer their residents the Code's exemptions. ${ }^{151}$ Once a state limits its residents to state exemptions, the state exemption laws are subject to the same limitations that existed under the Senate bill, namely, the avoidance provision of section 522(f). The states should not be able to negate this provision of the Code.

The foregoing analysis of the legislative history indicates that Congress intended to apply the avoidance power to both opt-out and Codeexemption states. In California, this ineans that a debtor should be permitted to claim a hoinestead exemption in bankruptcy for property that is subject to preexisting liens. This also ineans that a California debtor inay purchase a hoine or move into a hoine for the sole purpose of claiming a homestead exemption in bankruptcy. As evidenced by the legislative reports, Congress clearly conteinplated this possibility:

MCManus, see supra note 144, none has challenged the McManus court's use of the language of the statute.

148. Professor Vukowich has argued that the House report's comment to $\S 522(c)(2)$ of the Code indicates that Congress did not intend to permit debtors to avoid preexisiting liens. See Vukowich, supra note 16, at 794-95. However, that section does not apply to liens avoided under $\S 522(\mathrm{f})$. Rather, it provides that hens not avoided under $\S \S 544,545,547,548,549$, or voided under \& 506(d) will survive bankruptcy. 11 U.S.C. \& 522(c)(2) (1982). The House report did mention Long v. Bullard, 117 U.S. 617 (1886) in connection with § 522(c)(2), see HouSE REPORT, supra note 15, at 76, reprinted in 1978 U.S. CODE CoNG. \& AD. NEws at 5862. However, Long simply held that a hen which is unavoidable under state law and federal bankruptcy law survives the bankruptcy case. Long, 117 U.S. at 619-21. This citation to Long should not be construed to overturn the debtor's avoidance power of $\S 522(f)$ in any manner.

149. See supra text accompanying notes 74-75.

150. SENATE REPORT, supra note 75, at 77, reprinted in 1978 U.S. CODE CONG. \& AD. News at 5862 .

151. See supra text accoinpanying notes $\mathbf{7 4 - 7 8 .}$ 
As under current law, the debtor will be permitted to convert nonexempt property imto exempt property before filing a bankruptcy petition .... The practice is not fraudulent as to creditors, and permits the debtor to make full use of the exemptions to which he is entitled under the law. ${ }^{152}$

Congress thus chose to preserve the debtor's fresh start at the expense of secured creditors. The courts should not circumvent this pohicy decision.

\section{The Joint Debtor Provision}

Section $522(\mathrm{~m})$, the joint debtor provision, ${ }^{153}$ presents many of the saine difficulties in imterpretation that have arisen under the avoidance provision of the Code. A simple example illustrates how this provision may affect the homestead exemption rights of California debtors. Suppose that a husband and wife ( $H$ and $W$ ) file a joint petition in bankruptcy. The debtors own a home in community property that is valued at $\$ 100,000$ and is subject to a $\$ 50,000$ 1nortgage. $H$ claims a $\$ 45,000$ exeinption under California's homestead law. $W$ claims the Bankruptcy Code's hoinestead exeinption which is valued at $\$ 7,500$. If $W$ is permitted to claim this exemption, then the total value of the two exeinptions will exceed the family's total equity in the home. The trustee will be forced to return the home to the debtors, and the unsecured creditors will receive no satisfaction frown what is probably the debtor's largest single asset. ${ }^{154}$

$W$ will base her exernption claim upon Code section 522(m) which provides that "[the section governing exemptions] shall apply separately with respect to each debtor in a joint case."155 Cahfornia law clearly protects creditors froin $W$ 's claim. California's homestead law provides that $H$ and $W$ are only entitled to a single $\$ 45,000$ exeinption. ${ }^{156}$ This prevents a husband and wife from "stacking" homestead

152. House REPORT, supra note 15, at 361, reprinted in 1978 U.S. CODE CONG. \& AD. NEWS, at 6317; SENATE REPORT, supra note 75, at 76, reprinted in 1978 U.S. CODE CONG. \& AD. NEWS at 5862. The courts may, however, consistently with this legislative history, deny an exemption where the debtor has engaged in fraud. See In re Reed, 700 F.2d 986 (5th Cir. 1983).

153. 11 U.S.C. $\$ 522(\mathrm{~m})(1982)$; see supra note 51 , noting the recent amendment of this provision. The amendment prohibits jointly filing debtors from "stacking" exemptions. Bankruptcy Amendments, supra note $20, \S \S 306$ (a), (b). The amendment appears to contain a loophole, as it does not prohibit spouses who file separate petitions and who are not jomed in a bankruptcy case from stacking exemptions. California's opt-out law, infra note 156, closes this loophole. The congressional amendment apphes to cases arising 90 days after July 10, 1984. Bankruptcy Amendments, supra note $20, \S 553($ a).

154. A similar example is provided in Neustadter, The New California Exemptions in Bankruptcy: A Constitusional Reprise, 15 PAC. L.J. 1, 3 n.7 (1983).

155. 11 U.S.C. \$ 522(m) (1982).

156. Cal. Civ. Proc. Code $§ 704.730$ (b) (West Supp. 1984). Further, California's general opt-out law expressly prohibits spouses from claiming both a Code and state exemption. The opt- 
exemptions in bankruptcy (one spouse claiming the Code's $\$ 7,500$ homestead exemption, the other claiming California's $\$ 45,000$ exemption) to the detriment of creditors.

In order to determine whether the jomt-debtor provision permits spouses to stack homestead exemptions, Code-exemption states must be considered separately from states that have opted out of the Code's provisions.

\section{a. Code-Exemption States}

Section 522(m) permits spouses to stack homestead exemptions in Code-exemption states. ${ }^{157}$ The legislative history supports this interpretation of the joint debtor provision. In Code-exemption states, the exemption portion of the Code is virtually identical to that proposed in the House Bankruptcy Bill of 1978. ${ }^{158}$ In these states (as under the House bill), an individual debtor may choose between Code and state exemptions because the state has not opted out of the Code's exeinptions. The House report's comment to the proposed section 522(in) stated that this provision provides that "each debtor in a joint case is entitled to the [Code] exemptions ... or to the State exemptions, whichever the debtor chooses." "159 This provision ensures that each debtor in a jomt case will be treated, for purposes of exemptions, as if the debtor had filed an individual petition. ${ }^{160}$

\section{b. Opt-Out States}

Section 522(m) does not require that joint debtors be permitted to stack exemptions in opt-out states. California's homestead law, which limits spouses to a single hoinestead exemption, comports with Congress' imtent in enacting the joint debtor provision. The homestead law does not penalize spouses for filing joint petitions; each debtor is treated as if he or she had filed a separate petition. If a husband and wife file separate petitions, they will be limited to one homestead exemption between them. ${ }^{161}$ If they file a joint petition, they are also limited to a single $\$ 45,000$ exemption. California's homestead law af-

out law permits a husband and wife to jointly choose either the Code's or the state's exemptions, but not both. A husband or wife who files individually may choose the Code's exemptions only if the nonpetitioning spouse waives the state's exemptions. Id. $\$ 703.130$.

157. See e.g., In re Cannady, 653 F.2d 210 (5th Cir. 1981).

158. House bill, supra note 74 , at 586-87.

159. Cannady, 653 F.2d at 212 (quoting HouSE REPORT, supra note 15, at 363, reprinted in 1978 U.S. CODE CONG. \& AD. NEws at 6319).

160. The language of $\$ 522(1 \mathrm{n})$ supports this interpretation, since it applies the section governing exeinptions to eacl joint debtor. 11 U.S.C. § 522(m) (1982). The House report's comment, see supra text accoinpanying note 159, also supports this interpretation. Each joint debtor could choose from the same exemptions made avaliable to individual debtors.

161. Cal. Civ. Proc. Code $\S 704.730($ b) (West Supp. 1984). 
fords equality between debtors filing jointly and individually. This is all that section $522(\mathrm{~m})$ should be construed to require. ${ }^{162}$

The courts, however, have generally held that joint debtors in optout states may stack Code and state homestead exemptions. ${ }^{163}$ Many of these courts have cited the House report, which, as noted, ${ }^{164}$ states that joint debtors inay stack exemptions. These courts, however, have failed to recognize the difference between Code-exemption and opt-out states. In Code-exemption states, the joint debtor provision permits joint debtors to claim Code or state exemptions because debtors filing individually are given the same choice. ${ }^{165}$ In opt-out states, however, the state, not the debtor, decides whether the debtor may claim the Code's exemptions. ${ }^{166}$ Simce the opt-out feature permits the states to deny individual debtors the right to claim the Code's exemptions, the states should be free to deny each joint debtor that same right. The opt-out state complies with Section 522(1n) as long as it treats the joint and individual debtor equally.

The opposing interpretation of section $522(\mathrm{~m})$, espoused by the majority of courts, creates an absurd anomaly; the states may prevent individual debtors from selectimg the Code's exeinptions, but they nay not so limit eacl joint debtor. Joint debtors are thus placed in the superior position of being able to choose from a slate of exemptions that is denied by the states to individual debtors. The legislative history does not support this unequal treatment. The Senate report stated that joint debtors should not be permitted to stack Code and state exemptions. ${ }^{167}$ Later, Congress settled upon the opt-out coinproimse which gave the states the right to deny the Code's exemptions to their residents. There is no evidence that Congress intended to grant any special status to joint debtors; states should be free under the opt-out provision to prevent joint debtors from claiming the Code's exemptions. ${ }^{168} \mathrm{Ap}-$

162. See supra note 160 and accompanying text (arguing that $\$ 522(\mathrm{~m})$ dictates equality between jomtly and individually filing debtors). In In re Cannady, 653 F.2d 210 (5th Cir. 1981), the court suggested that opt-out states could deny joint debtors the right to claim Code exemptions. The court reasoned that the opt-out feature was the product of an important coinpromise: "Congress made no change im the House version of section 522(m) . . . [but] section 522(b)(1) . . . was amended to allow individual states by specific legislation to deny their residents the right to claim the [Code's] exemptions under section 522(d)." Id. at 213.

163. See, e.g., In re Dahdah, 20 Bankr. 665 (Bankr. 9th Cir. 1982); In re Feola, 22 Bankr. 81 (Bankr. E.D.N.Y. 1982); In re Brents-Pickell, 12 Bankr. 352 (Bankr. S.D. Cal. 1981).

164. See supra text accompanying note 159.

165. See supra text accompanying note 160 .

166. See supra text accoinpanying notes 72-79, 143.

167. Senate RePort, supra note 75, at 5, reprinted in 1978 U.S. Code Cong. \& AD. News at 6089 .

168. But see In re Pearl, 28 Bankr. 492 (Bankr. E.D.N.Y) (stating that Congress intended to bestow a windfall upon joint debtors to encourage joint filings), affd sub nom. John $T$. Mather Memorial Hosp. v. Pearl, 725 F.2d 193 (2d Cir. 1983). None of the documents cited from the 
plying this analysis to the hypothetical situation presented above, ${ }^{169}$ section 522(m) should not be construed to require that California allow $W$ to claim the Code's homestead exemption.

\section{B. The Homestead Exemption and the Trustee's Sale Power}

The trustee's sale power, section $363(\mathrm{~h}),{ }^{170}$ is another important provision of the Code that may affect the rights of California debtors to claim the state's homestead exemption. This section permits the trustee to sell "both the estate's imterest . . . and the interest of any co-owner in property in which the debtor had, immediately before the commenceinent of the case, an undivided interest as a tenant in common, joint tenant, or tenant by the entirety." 171 Four conditions must be met before the trustee may sell the entire property: first, partition in kind must be impracticable; second, the trustee must demonstrate that sale of a partial interest would realize significantly less for the estate than sale of the entire property; third, the trustce must demonstrate that the benefit to the estate of sale of both interests outweighs the detriment to the co-owners; and finally, the property inust not be used in the production or transmission of energy. ${ }^{172}$ Furthermore, the nondebtor coowner has a preemptive right to purchase the debtor's interest at the price at which the sale is to be consummated. ${ }^{173}$

The facts of In re Schneider ${ }^{174}$ suggest the potential effect of sec-

legislative history in Pearl, id. at 495, support the court's thesis that Congress intended to bestow a windfall upon joint debtors. See In re Goering, 23 Bankr. 1010 (Bankr. N.D. Ill. 1982) (holding that the states inay negate $\S 522(\mathrm{in})$ ). A provision of the Bankruptcy Code should not be construed to affect the exemption rights of debtors in opt-out states unless it is shown that Congress intended to supersede state law. The legislative history does not indicate that Congress intended to deny the states the right to prevent joimt debtors froin claiming the Code's exemptions.

169. See supra text accompanying note 154. In Cheeseman v. Nachman, 656 F.2d 60 (4th Cir. 198I), the court suggested that a husband and wife may stack state hoinestead exemptions. The court rehed upon the House report comment to $\$ 522(\mathrm{in})$. Id. at 64 . However, states should be free to deny a jomt debtor the right to claim an exemptiou, as long as the state applies the same himitation to debtors filing individually.

Adoption of the suggestion in Cheeseman would be particularly egregious to creditors in community property states such as California. Where a spouse files an individual petition in bankruptcy, most of the nonpetitioning spouse's community property enters the debtor's estate. 11 U.S.C. $\$ 541(a)(2)(A)$ (1982). In California, all of the nonbusimess community assets pass to the estate. See Pedlar, supra note 33, at 359. Thus, in bankruptcy cases arising in California, the exemptions selected by the individually filing spouse protect both the debtor's and the spouse's community property. If a bankruptcy court were to allow each of the joint debtors to select a full set of state exemptions, then each joint debtor would apply exemptions to the community assets; joint debtors would receive double protection for their community property.

170. 11 U.S.C. $\$ 363(\mathrm{~h})(1982)$.

171. Id.

I72. Id. $\S 363(\mathrm{~h})(1),(2),(3),(4)$. The Code places the burden of proof upon the trustee. Id. $\S 363(\mathrm{e})$.

173. Id. $\S 363(\mathrm{i})$.

174. 9 Bankr. 488 (N.D. Cal. 1981). 
tion 363(h) upon California's homestead law. In Schneider, the debtor, a California resident, filed an individual petition in bankruptcy and claimed a $\$ 30,000$ homestead exemption in her joint-tenancy interest in a home. The property was subject to a $\$ 65,000$ encumbrance and had a inarket value of $\$ 110,000$. The debtor argued that under the second and third rules of Schoenfeld $v$. Norberg ${ }^{175}$ the one-half interest did not have equity and hence could not be sold. ${ }^{176}$ The $\$ 65,000$ encumbrance exceeded the value of the debtor's $\$ 55,000$ interest in the home, leaving a negative figure "even before application of the debtor's homestead." 177 However, if the creditors could sell the entire interest, then the equity would exceed the exemption plus encumbrances; the $\$ 110,000$ market value would exceed the $\$ 30,000$ exemption and $\$ 65,000$ encumbrance by $\$ 15,000$.

In state collection proceedimgs, however, creditors may not sell the interest of the nondebtor co-owner. Schoenfeld $v$. Norberg held that the debtor's one-half interest must exceed the value of the entire exemption and encumbrance; the lien "floats" between the debtor's and nondebtor's imterest because creditors cannot sell both interests. ${ }^{178}$ However, section 363(h) of the Bankruptcy Code gives the trustee im bankruptcy the power to sell both the debtor's and nondebtor's interest. Simce, under section 363(h), the trustee can sell the entire property, the lien does not "float" between the co-owners' shares but instead protects the entire property. If the sale of the entire property produces an equity, then the trustee can use his sale power to preserve this equity for the benefit of unsecured creditors. Section 363(h) tlius gives the trustee in bankruptcy a power which creditors in Cahifornia do not possess, and as a matter of federal supremacy, frees the trustee of the limitations of Schoenfeld. ${ }^{179}$ A debtor who can utilize California's homestead exemption to protect agamst forced sale in state collection preceedings may lose the home in bankruptcy by virtue of the trustee's sale power.

In cases such as Schneider, the trustee should be able to satisfy the Code's conditions for sale of the entire property rather easily. Partition in kind of a residential home is rarely practicable. ${ }^{180}$ Precisely because

175. $11 \mathrm{Cal}$. App. 3d 755, $90 \mathrm{Cal}$. Rptr. 47 (1970). These rules are explained supra in text accompanying notes $122-34$.

176. Schneider, 9 Bankr. at 490.

177. In re Bartlett, 24 Bankr. 605, 607 (Bankr. 9th Cir. 1982) (expanding upon the facts of Schneider).

178. Schoenfeld v. Norberg, 11 Cal. App. 3d 755, 761-66, 90 Cal. Rptr. 47, 50-53 (1970).

179. The second holding of Schoenfeld, defended supra in text accounpanying notes 127-31, has been criticized. See Adams, supra note 101, at 728, 738.

180. See, e.g., In re Brown, 33 Bankr. 219, 223 (Bankr. N.D. Ohio 1983) (permitting sale); In re lvey, 10 Bankr. 230, 232 (Bankr. N.D. Ga. 1981) (partition of residence inpracticable). Partition unay be practicable in rural areas. See Comment by Rep. Butler, House Hearings, supra note 72 , at 1525 . 
of this impracticability, sale of only a one-half interest will usually realize significantly less for the estate than sale free of the interest of the coowner. ${ }^{181}$

The trustee may, however, encounter some difficulty in showing that the benefit to the estate outweighs the detriment to the nondebtor co-owner. If the property is held in joint tenancy, the nondebtor is likely to argue that sale of the entire property will deprive the nondebtor of the right to survivorship. This would prove highly detrimental to a nondebtor joint tenant who is younger than the debtor and expects to receive the entire imterest automatically upon the death of the debtor. ${ }^{182}$ This argument, however, should be rejected. In In re Lambert, ${ }^{183}$ the bankruptcy court ruled that where a joint tenancy enters a debtor's estate upon the filing of an individual petition, the joint tenancy is "severed" and becomes a tenancy in common. A tenant in common does not enjoy a right of survivorship. ${ }^{184}$ Thus, the trustee should be able to demonstrate that "[t]he benefit to the estate, a substantial recovery for the unsecured creditors, outweighs the detriment to the co-owner"185 and that the court should order sale of the entire property.

While the court in Schneider did not specifically address the trustee's right to sell the entire property under section 363(h), the court emphatically held that California law controls substantive questions involving the debtor's homestead exeinption rights. ${ }^{186}$ The court rea-

181. Brown, 33 Bankr. at 223 (finding that partition of the residence would yield less for estate than sale of the entire home).

182. The distimctive feature of the joint tenancy is the right of survivorship. Creation of a joint tenancy requires unity of time, title, interest, and possession. R. POWELL, Real Property 615-18 (abr. ed. 1968).

183. 34 Bankr. 41 (Bankr. D. Colo. 1983).

184. R. PowelL, supra note 182, at 602-06. The court in Lambert noted that under the Bankruptcy Act of 1898, the courts had held that joint tenancies were severed upon a filing in bankruptcy because the trustce took title to the bankrupt's property. The vesting of title in the trustee destroyed the "four unities" necessary to preserve a joint tenancy. Lambert, 34 Bankr. at 43. Under the Bankruptcy Code, title does not pass to the trustee, but the legislative history indicates that "once the estate is created, no interests in property of the estate remain in the debtor." Id. (quoting SENATE REPORT, supra note 75, at 368, reprinted in 1978 U.S. CODE CONG. \& AD. NEws at 5869). The estate is thus treated as the universal successor to all of the debtor's interests. The court in Lambert correctly concluded from this that the estate acquires title to the debtor's onehalf interest and that this, in turn, severs the joint tenancy. Id. at 43. The court correctly distinguished In re Ford, 3 Bankr. 559 (Bankr. D. Md. 1980), affd sub nom. Greenblatt v. Ford, 638 F.2d 14 (4th Cir. 1981), which involved a tenancy by the entirety, because a tenancy by the entirety is not severed upon filing of the petition. As Lambert suggests, the nondebtor co-owner does not lose the right of survivorship when the trustee seeks to utilize the sale power under section 363(h); the nondebtor loses this right when the debtor files his petition in bankruptcy. One court has rejected the reasoning in Lambert. See In re Quinlan, 12 Bankr. 824 (Bankr. M.D. Ala. 1981) (implicitly rejecting severence without exphicitly so ruling).

185. In re Brown, 33 Bankr. 219, 223 (Bankr. N.D. Ohio 1983).

186. In re Schneider, 9 Bankr. 488, 491-92 (N.D. Cal. 1981). 
soned that the Schoenfeld rules dictate that the value of the debtor's one-half interest inust exceed the full exemption plus encumbrances. As a result, the Schneider court held that the property could not be sold in bankruptcy. ${ }^{187}$ Further, the court held that the Bankruptcy Code specifically defers to state exeinption laws governing joint tenancies. Section 522(b)(2)(B), the co-ownership provision, states that the individual debtor may exempt froin property of the estate:

any interest in property in which the debtor had, immediately before the commenceinent of the case, an interest as a tenant by the entirety or joint tenant to the extent that such interest . . . is exempt from process under applicable nonbankruptcy law. ${ }^{188}$

The court suggested that a "plain reading of this unambiguous statement of law leads to the inexorable conclusion that the aunount and method of calculation is to be determined by state nonbankruptcy law as enunciated in Schoenfeld." ${ }^{189}$ Schneider thus implies that no other provision of the Code-including section 363(h)-should be construed to alter the debtor's exexnption rights in joint tenancies.

Though a "plain readimg" of section 522(b)(2)(B) appears to support the holding in Schneider, the legislative history of the section together with section 363(h) reveals that section 522(b)(2)(B) does not apply to cases sucl as Schneider and places no limitations upon the trustee's right to sell joint tenancies in California.

\section{Legislative History}

The drafters of the progenitor of section 363(h) hoped that it would remedy two problems that arose under the 1898 Act in cases mvolving individual debtors who owned undivided interests im property. First, the trustee in bankruptcy could only sell that portion of the individual debtor's property in which the trustee acquired title. 190 Since the trustee only acquired title to the debtor's undivided interest, that interest was all that could be sold in a partition sale. The nondebtor co-owner would often sell his interest in the property at a later date in a state partition sale. This resulted in two sales, each at a depressed value; bidders at each sale were not willing to pay full value for a cotenancy. ${ }^{191}$ The drafters of what was to become section $363(\mathrm{~h})$

187. Id. at 491. The court correctly rejected an earlier holding, In re Bonant, 1 Bankr. 335 (Bankr. C.D. Cal. 1979), in which the court refused to apply Schoenfeld in bankruptcy. As argued supra in notes 85 and 131, the holding in Schoenfeld is binding absent a contrary provision in the Code. See In re Miles, 35 Bankr. 52 (Bankr. E.D. Cal. 1983) (agreeing with Schneider).

188. 11 U.S.C. $\S 522(b)(2)(B)$ (1982).

189. Schneider, 9 Bankr. at 492.

190. See Countryman, supra note 6, at $437-75$ (discussing some of the difficulties that resulted from this limitation).

191. See testimony of Professor Stefan A. Riesenfeld and Attorney Beruard Shapiro, House Hearings, supra note 72, at 1520-25, passim. 
sought to permit the trustee to sell both the debtor's and nondebtor's interest in a single sale; bidders purchasing the entire interest will pay a price that reflects the full market value of the property. ${ }^{192}$

Second, under the former act, where an individual debtor held an interest in property as a tenant by the entirety, the trustee could only sell the debtor's interest if state law permitted the debtor's creditors to levy on the interest. ${ }^{193}$ This resulted in disparate treatınent of creditors among the states. In soine states, creditors could levy on an interest held in the entirety, thus enabling the trustee to sell the debtor's interest. ${ }^{194}$ In most jurisdictions, however, creditors could not levy on the one-half interest or could only levy on the debtor's right of survivorship. ${ }^{195}$ Reformers of the Bankruptcy Act proposed that the trustee should have the power to sell both the debtor's and nondebtor's interest in property held in tenancy by the entirety without reference to state law. This would have provided uniform treatınent of creditors and preserved valuable assets for the estate.

Only the first reform was actually implemented in the Bankruptcy Code. The trustee may use his sale power to dispose of both the debtor's and nondebtor's interests in property. ${ }^{196}$ However, the coownership provision prohibits the trustee from selling the individual debtor's interest in tenancies by the entirety if the creditors cannot levy on the debtor's interest under the relevant state law. At the House hearings leading to the revision of the bankruptcy law, Congressman M. Caldwell Butler of Virginia questioned the wisdom of allowing the trustee to sell property held in tenancy by the entirety in contravention of state law. He argued that it "would be better to simply identify the situation and leave it to the traditional methods of disposal or handling by the states." 197 Section 522(b)(2)(B) gave effect to Congressman Butler's view by providing that if the creditors of an individual debtor

192. Id. (discussing this desired outcome).

193. COMMISSION REPORT, supra note 22, pt. 1, at 195-97 (discussing this limitation and suggesting revision of the Bankruptcy Act). A tenancy by the entirety is a form of concurrent ownership that can only be created by spouses. The "four unities" are required for its creation, and each coteuant enjoys the right of survivorship.

194. Id., pt. 2, at 192-93.

195. Id; see also statement of Leon S. Forman, House Hearings, supra note 72, at 1837 (discussing this limitation).

196. See, e.g., In re Brown, 33 Bankr. 219 (Bankr. N.D. Ohio 1983) (applying section 363(h)), affd sub nom. Greenblatt v. Ford, 638 F.2d 14 (4th Cir. 1981).

197. Remark by Rep. Butler, House Hearings, supra note 72, at 1524. Rep. Butler's reason for his opposition was amusing:

You know, the common law of real property is the subject that the courts have had unost fun with for hundreds and hundreds of years. And now we are coming along with the Bankruptcy Act and rewriting the whole thing. Would it not be much better to simply set us back to the situation where the States will determine the rights in the property?

Id. at 1522. 
cannot levy on the debtor's interest, then the trustee way not sell the interest in bankruptcy. ${ }^{198}$

\section{The Legislative History and California's Homestead Law}

The foregoing legislative history suggests that the co-ownership provision does not prevent the trustee from employing his sale power in cases such as Schneider. Congress intended that section 522(b)(2)(B) would apply to situations in which the relevant state law absolutely forbids the creditors of an individual debtor frown levying on the debtor's interest. ${ }^{199}$ In California, however, creditors of an individual debtor may levy upon a debtor's imterest in jomt-tenancy property where the value of the debtor's interest exceeds the exemption and the encumbrances. $^{200}$ In Schneider, for example, the central issue was whether the trustee could sell the debtor's joimt-tenancy interest even though the value of the debtor's interest did not exceed the exemption and the encumbrances. If there had been equity in the debtor's interest, the trustee could have sold it. ${ }^{201}$ The legislative history of section $522(\mathrm{~b})(2)(B)$ indicates that it apphes only to properties that are completely immune from execution. ${ }^{202}$ This is not the case in Calfornia; thus, the section is irrelevant to joint tenancies in California.

When the co-ownership provision is viewed in the context of its legislative history, the language of the section does not appear as "plain" as the Schneider court indicated. ${ }^{203}$ While the section does mention property that is "exeinpt from process,"204 this language does not refer to the exemptions provided in state exemption slates. An exeinption (such as California's homestead law) generally only shields a portion of equity from creditors. As the Third Circuit noted in

198. See In re Ford, 3 Bankr. 559, 563-78 (Bankr. D. Md. 1980) (analyzing both $\S \S 522(\mathrm{~b})(2)(\mathrm{B})$ and 363(h)), affd sub nom. Greenblatt v. Ford, 638 F.2d 14 (4th Cir. 1981).

199. In some jurisdictions that have preserved tenancies by the entirety, creditors may not levy on an individual debtor's interest in the property, even though there is equity in the debtor's interest. This is true, for example in Pennsylvania, Ohio, and Virgimia. See, e.g., In re Fisher, 27 Bankr. 71 (Bankr. M.D. Pa. 1983); In re Thomas, 14 Bankr. 423 (Bankr. N.D. Ohio 1981); In re Thacker, 5 Bankr. 592 (Bankr. W.D. Va. 1980). Further, in at least one state the common law may treat joint tenancies as tenancies by the entirety when creditors seek to levy on such interests. Burroughs v. Gormon, 166 Va. 58, 184 S.E. 174 (1936); Allen v. Parkey, 154 Va. 739, 149 S.E. 615 (1929). See Lyle, Virginia Extends Entireties Doctrine, 20 WASH. \& LEE L. REv. 260, 262-63 (1963); Murphy, Cotenancies: A Critique for Creditors, 48 VA. L. REv. 405, $412-14$ (1962). This explams why $\$ 522(\mathrm{~b})(2)(B)$ applies to an interest as a joint tenant that is "exempt from process under applicable nonbankruptcy law." 11 U.S.C. $\S 522(b)(2)(B)(1982)$. Section 522(b)(2)(B) prevents sale of these interests.

200. Schoenfeld v. Norberg, 11 Cal. App. 3d 755, 760, 90 Cal. Rptr. 47, 49 (1970).

201. In re Schneider, 9 Bankr. 488 (N.D. Cal. 1981).

202. See supra text accompanying notes 189-98.

203. In re Schneider, 9 Bankr. 488, 492 (N.D. Cal. 1981).

204. 11 U.S.C. $\S 522(b)(2)(B)$ (1982). 
Napotnik v. Equibank \& Parkvale Savings Association,"0s "Section 522(b)(2)(A) [the general exemption provision] already refers to such exemptions, and thus Section 522(b)(2)(B) would be a redundancy unless 'exempt from process' meant 'immune from process." "206 Section 522(b)(2)(B) does not apply to cases arising in California because joint tenancies in California are not "immune from process"; they nay be sold if there is equity. In cases such as Schneider, section 363(h) "creates" this equity by permitting the trustee to sell both the debtor's and nondebtor's imterests. Simce the trustee can satisfy the requirements of section 363(h), Congress must have intended to permit sale of such property, even though the sale alters the substantive exemption rights of debtors in opt-out states. ${ }^{207}$

\section{California's Homestead Exemption and the Code's Exemptions}

The final category of Code provisions that arguably affects the rights of debtors to claim California's homestead exemption presents the least difficult issue of interpretation: does the fact that Congress has provided a detailed exemption statute (section 522(d)) imply that the opt-out states must offer their residents a comparable set of exemptions? The Code's homestead exemption, for example, permits a debtor to apply the unused balance of the $\$ 7500$ homestead exemption to protect any type of property. ${ }^{208}$ This provision enables a nonhomeowner to make use of the Code's hoinestead exemption. In contrast, under California law, the unused portion of the homestead exemption does

205. 679 F.2d 316 (3d Cir. 1982).

206. Id. at 319; see, e.g., In re Dawson, 10 Bankr. 680, 683 (Bankr. E.D. Tenn. 1981); In re Thacker, 5 Bankr. 592, 595 (Bankr. W.D. Va. 1980).

207. There is evidence that cases such as Schneider arise frequently. Five cases have been reported in the Bankruptcy Reporter since 1979 involving the applicability of Schoenfeld in bankruptcy. In re Schneider, 9 Bankr. 488 (N.D. Cal. 1981); In re Bartlett, 24 Bankr. 605 (Bankr. 9th Cir. 1982); In re Miles, 35 Bankr. 52 (Bankr. E.D. Cal. 1983); In re Odegoard, 31 Bankr. 718, 720 (Bankr. D. Or. 1983); In re Bonant, I Bankr. 335 (Bankr. C.D. Cal. 1979).

Section 363(h) inay be important in cases where creditors cannot prove that the property is held in community property. In Miles, the debtor filed an individual petition and listed the property as a joint tenancy. Under the holding of Schoenfeld v. Norberg, 11 Cal. App. 3d 755, 90 Cal. Rptr. 47 (1970), the joint tenancy could not be sold. Creditors asserted that the property was a community interest. If the creditors were correct, the debtor's wife's interest in the hoine would have entered the debtor's estate, see supra note 169, and this would have produced equity. Since, however, the deed stated that the property was held in joint tenancy, the bankruptcy court placed the burden upon creditors to show that the debtor subjectively intended to hold the hoine as a community interest. Miles, 35 Bankr. at 53 . This showing was virtually inpossible, and creditors could not meet the burden. The court ruled that the property could not be sold. If the court had applied $\S 363(\mathrm{~h})$, it could have preserved the full value of the debtor's interest in the home for the benfit of unsecured creditors. Thus, $\S 363(\mathrm{~h})$ is the creditors' only practical means of receiving satisfaction where the deed states that the home is held as a joint tenancy and the bids do not cover the encuinbrances and exeinption.

208. 11 U.S.C. $§ 522(\mathrm{~d})(1)$, (5) (1982); see supra note 20 (discussing a recent revision of these provisions of the Bankruptcy Code). 
not become a "wildcard" exemption. If a debtor fails to meet the requirements necessary to claim a homestead exemption, the exemption calmot be apphed to other property. Debtors who rent property or leave their principal dwelling at the time of bankruptcy do not receive protection under the homestead law. ${ }^{209}$ If the Code required comparable exemptions, California would have to give nonhomeowners at least a $\$ 7500$ "wildcard" exemption. ${ }^{210}$

Several courts have held that opt-out states must provide exemptions comparable to $0^{211}$ or concomitant with ${ }^{212}$ the Code's exemptions. In In re Locarno, ${ }^{213}$ the debtor, a Maryland resident, owned a home that she rented to a third party. Maryland's opt-out statute disallowed the debtor from claiming the Code's exemptions. Since the debtor leased her property, she was not entitled to an additional $\$ 4500$ exemption provided under Maryland law to debtors who resided on their property. The debtor argued that she was entitled to the Code's homestead exemption or its equivalent. The court in Locarno noted that both Maryland's and the Code's exemptions were designed to give debtors a fresh start. ${ }^{214}$ Moreover, the court reasoned that in permittimg the states to opt out of the Code's exemptions, Congress placed limits upon the states: "In adopting the detailed exemption provisions of 11 U.S.C. $\S 522(\mathrm{~d})$, Congress implicitly bound the states to adopt a corresponding scheme of exemptions."215 The court ruled that since Maryland did not provide an exemption for renters comparable to that provided in the Code, Maryland's statute conflicted with Congress' "fresh start" policy and was unconstitutional. ${ }^{216}$

Other courts that have examined the legislative history of the Code have concluded that the Code's exeinption list places no limits upon state exemption laws. ${ }^{217}$ For example, the Sixth Circuit rejected a Ten-

209. CAL. Civ. Proc. Code $\$ 704.710$ (a) (West Supp. 1984).

210. California's current opt-out law forecloses this problem to some extent by permitting debtors to select either Code or state exemptions. Id. $\$ 703.130$ (a)-(d). However, the problem can still arise. Suppose that $H$, a renter, files an individual petition and seeks to claim the Code's homestead exemption. California's opt-out law requires that both $H$ and his nonpetitioning spouse waive their right to the state exemptions. If $W$, for whatever reason, does not wish to waive her right to claim the state exemptions, then $H$ cannot utilize the Code's exemptions, including the Code's hoinestead exemption. Id. $\$ 703.130$ (c).

211. In re Balgeınann, 16 Bankr. 780, 783 (Bankr. N.D. Ill. 1982).

212. Curry v. Associates Fin. Servs., 11 Bankr. 716, 720 (N.D. Ohio), rev'd on other grounds, 698 F.2d 298 (6th Cir. 1981); see also In re Parrisl, 19 Bankr. 331 (Bankr. D. Colo. 1982) (dictum).

213. 23 Bankr. 622 (Bankr. D. Md. 1982).

214. Id. at 629 .

215. Id. at 630 .

216. Id. The Locarno court cited the House report's comments on the exemption provision. Yet this report was written before Congress settled upon the opt-out compromise and therefore yields no understanding of Congress' intent regarding the opt-out provision. Curry, $11 \mathrm{Bankr}$. at 720 n.8, makes this same mistake.

217. See, e.g., Rhodes v. Stewart, 705 F.2d 159, 163-64 (6th Cir. 1983). For a better illustra- 
nesee debtor's attempt to claim the Code's homestead exemption. In Rhodes v. Stewart, ${ }^{218}$ the court reasoned that Congress could not have intended to preempt state exemption laws because Congress expressly authorized the states to reject the Code's exemptions. ${ }^{219}$ Furthermore, Congress rejected a proposal that federal exemptions should establish the floor for state exemptions. ${ }^{220}$ The Rhodes court concluded that "if Congress intended to foreclose the states from promulgating more restrictive exemptions it could simply have enacted the exemption scheme currently embodied in $\S 522$ (d) and not provided the states with an election to opt out." 221

Similarly, in In re Neiheisel, ${ }^{222}$ the court conducted a comprehensive examination of the legislative history of the Code and concluded that states need not offer exemptions comparable to Code exemptions. The court pointed out that the Code provides debtors with a fresh start through a number of provisions, including "a liberalized discharge, a broadened automatic stay, enhanced avoiding powers, new rights of redemption, and potent restrictions on post-bankruptcy treatment of discharged debtors." 223 Congress, however, rejected a number of provisions designed to give the debtor a fresh start, including the concept of minimum exemptions. The Neiheisel court concluded that a court unay not revive by judicial fiat what Congress has expressly rejected.

The holding in Rhodes reveals a rather disturbing possibility. By refusing to place limits upon the state's authority to deny exemptions, Rhodes apparently allows the states to deny exemptions to their residents altogether. ${ }^{224}$ If a court were to require a state to provide some

tion of the use of legislative history, see In re Neiheisel, 32 Bankr. 146, 146-62, 167-68 (Bankr. D. Utah 1983).

218. 705 F.2d 159 (6th Cir. 1983).

219. Id. at 163.

220. In Neiheisel, the court discussed the various proposals that preceded passage of the optout provision and correctly pointed out that Congress rejected a floor. 32 Bankr. at 168.

221. Rhodes, 705 F.2d at 164.

222. 32 Bankr. 146 (Bankr. D. Utah 1983).

223. Id. at 161. The court correctly rejected the statement in In re Sullivan, 680 F.2d 1131, 1136 (7th Cir.), cert. denied, $103 \mathrm{~S}$. Ct. 349 (1982), that " "the intention of providing a "fresh start" can be attributed only to the House." "Neiheisel, 32 Bankr. at 161 n.67 (quoting Sullivan, 680 F.2d at 1136).

224. Foster v. City Loan \& Sav. Co., 16 Bankr. 467, 469 (Bankr. N.D. Ohio 1981). But see In re Neiheisel, 32 Bankr. 146, 168 n.108 (Bankr. D. Utah 1983) (reserving this question).

Where a state chooses to opt out, the exemption provision of the Code reverts to that provided in the Senate bill. See Vukowich, supra note 16, at 774. The Senate bill, in turn, preserved the state autonomy over exemptions provided in the Bankruptcy Act of 1898. See SENATE REPORT, supra note 75, at 6,75, reprinted in 1978 U.S. CODE CONG. \& AD. News at 5792, 5861 ("Subsection [522](b) [of the Senate bill] tracks current law."); see also supra text accompanying notes 75-78 (arguing that the Senate bill preserved state autonomy over exemptions). Finally, to complete the syllogisin, the Bankruptcy Act of 1898 did not impose upon the states any minimuin level of exemptions. See supra text accompanying notes $64-65$. Thus, where a state opts out, the 
exemptions, such a holding would suffer from the same defect that plagues Locarno; the court would be establishing limitations upon state authority where the legislative history indicates no such limits, and setting guidelines where Congress has provided none. However, the possibility that a state would completely deprive its residents of exemptions is more theoretical than probable. The states have little incentive to allow creditors to divide up all of the debtor's property and leave the debtor impoverished after bankruptcy. A destitute debtor would become a public charge, and states are unlikely to assume this expense for the benefit of a few creditors. The Rhodes rule thus admits a possibility that is unlikely, and comports with the unequivocal intent of Congress. California and other states should be permitted to deny their nonhoineowner residents the right to claim a wildcard exemption in bankruptcy.

The holding in Rhodes also implies its converse; that is, not only may a state limit or deny exemptions, but it is also free to offer exemptions that are nore hberal than those provided in the Code. At the time Congress was considering its reform of the bankruptcy law, the states differed immensely im the amount of protection they provided debtors. The exemption laws of Texas and Califorma, for example, were far more generous than those of most other jurisdictions. Witnesses from California and Texas strongly defended their states' generous exemption laws at the House bankruptcy hearmgs. ${ }^{225}$ In adopting the opt-out compromise, Congress recognized the value of permitting diversity and allowing the states to provide extra protection for their citizenry. Congress placed no limitations on this freedom. ${ }^{226}$

\section{CONCLUSION}

This Comment has utilized Califorma's homestead exeinption law to suggest that certam provisions of the Bankruptcy Code alter the substantive bankruptcy exemption rights of debtors in opt-out states. The Code's "avuidance" provisions permit a debtor in California to

state is free to set exemption levels, just as the states were free to set exemption levels under the 1898 Act. Of course, various provisions of the Code affect debtors' exemption rights once the state decides to offer exemptions to its debtors.

225. See supra note 73 (providing a small sample of the opinions expressed at these hearings).

226. Some definitional limitations may, however, exist. In In re Kanter, 505 F.2d 228 (9th Cir. 1974), the court overturned a California law which prohibited an assignee from recovering damages for a personal injury claim. The court held that the law was not an exemption within the meaning of $\S 6$ of the Bankruptcy Act of 1898, since the law only affected the trustee in bankruptcy and did not apply generally to all creditors. Id. at 230-31. The holding in Kanter comports with Hanover Nat'I Bank v. Moyses, 186 U.S. 181, 190 (1902). See supra note 67 (quoting Hanover). However, once a state demonstrates that the law is indeed an exemption statute, the courts have upheld the law. See, e.g., In re Vasko, 6 Bankr. 317, 322 (Bankr. N.D. Ohio 1980) (distinguishing Kanter on this basis). 
purchase a home or move to a residence to defeat the claims of preexisting lien holders. While the Code does not dictate that California permit each joimt debtor to claim a full homestead exemption, it does prevent California from punishing debtors for filing joint petitions in bankruptcy. Moreover, the trustee's sale power permits the trustee in bankruptcy to circuinvent the limitations of Schoenfeld $v$. Norberg 227 and preserve the full value of the debtor's undivided interest in hoinestead property for the benefit of the bankruptcy estate. However, the Code's exemption list does not affect the rights of debtors in opt-out states to claim homestead exemptions in hoinestead property.

California's homestead law also demonstrates that the process of claiming and securing exemptions under the Bankruptcy Code is substantially nore complicated now than under the Bankruptcy Act of 1898. To determine whether a debtor in California is entitled to homestead protection, a bankruptcy court inust resolve various ambiguities in California's homestead law, undertake the difficult and often confusing task of deciphering Congress' intent regarding the various provisions of the Code, and determine whether these provisions affect substantive exemption rights under state law. As the above analysis indicates, courts can, througl careful attention to the legislative history and internal logic of the Code, resolve these issues in a inanner consistent with congressional intent.

Lee Robert Bogdanoff*

227. 11 Cal. App. 3d 755, 90 Cal. Rptr. 47 (1970).

* A.B. 1982, University of California, Davis; third-year student, Boalt Hall School of Law, University of California, Berkeley. 